DePuy's Popular Poultry and Pet Stock Book No. 4

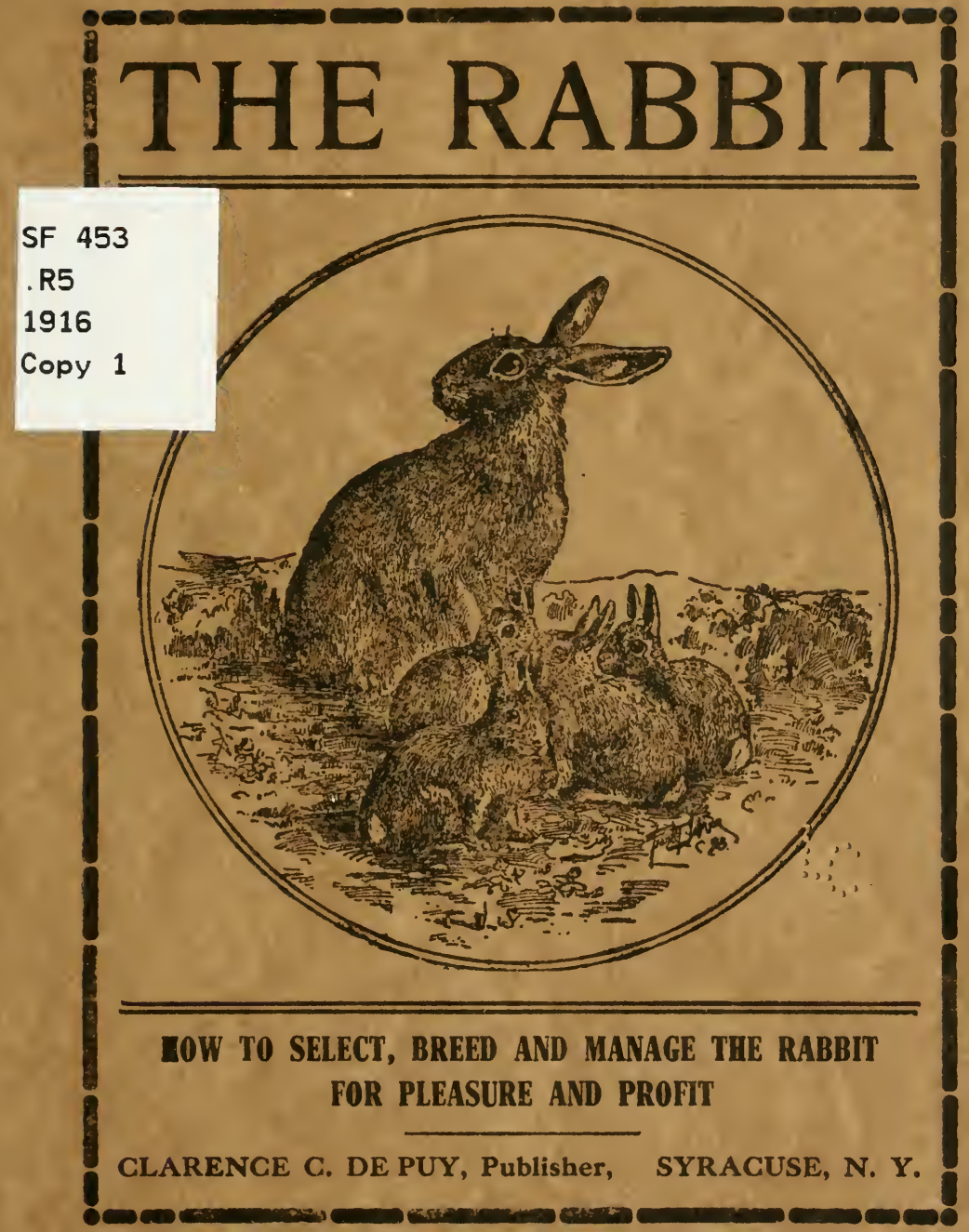




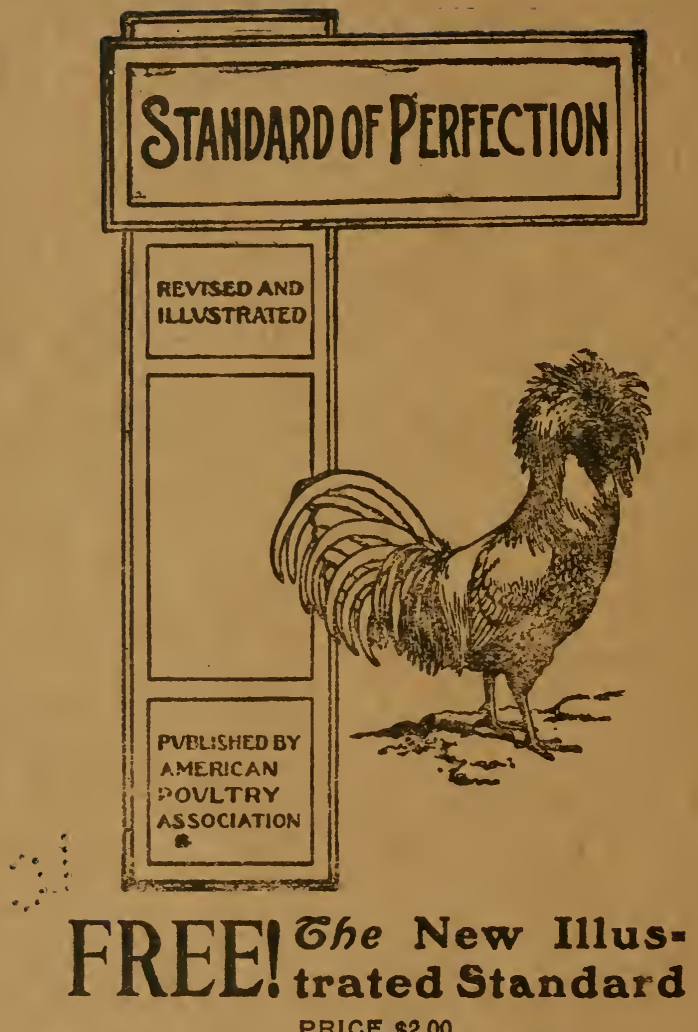

\section{PRICE $\$ 2.00$}

Readers of the American Poultry Advocate can obtain a copy of this handsome New Standard of Perfection FREE by sending FOUR DOLLARS for eight yearly subscriptions to the American Poultry Advocate, or the Standard of Perfection and the American Poultry Advocate one year for $\$ 2.25$. Orders promptly filled. ORDER NOW!

$$
\text { Address: }
$$

American Poultry Advocate, Syracuse, N. Y. 


\section{... THE}
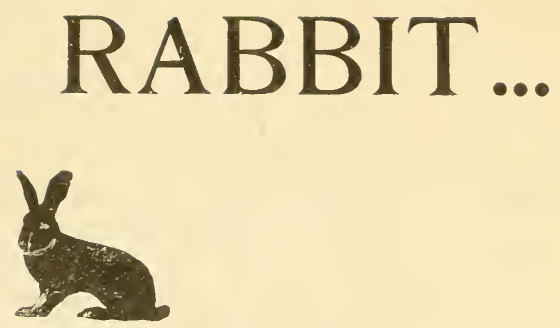

HOW TO SELECT, BREED AND MANAGE THE RABBIT FOR PLEASURE OR PROFIT.

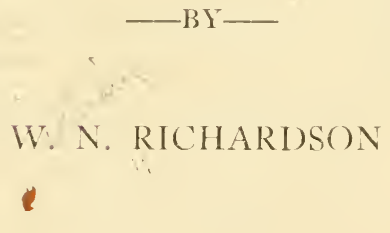

SIRACUSE, I. Y.

CLARENCE C. DEPLY,

PUBLISHER

1916 
Copyrighted 1894, by W. N. RICHARDSON Copyrighted 1896, by Clarence C. De Puy Copyrighted 1899, by Clarence C. De Puy Copyrighted 1900, by Clarence C. De Puy Copyrighted 1901, by Clarence C. De Puy Copyrighted 1906, by Clarence C. De Puy Copyrighted 1916, by Clarence C. De PuY 


\section{INTRODUCTION}

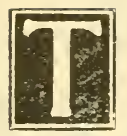

$\mathrm{HE}$ demand for a hand book on the Rabbit, explaining in a practical manner the mysteries of rabbit culture, treating especially on the care and management of the Belgian Hare, is the only excuse for perpetuating this volume on the indulgent public.

In the main the writer's actual experience is given; while for information requiring greater experience and familiarity with the Rabbit, such eminent authorities as Messrs. Watmough, Mason and Knight, of the land of fanciers, "England," are quoted.

If, by following the plans recommended, the privations and sufferings of an animal so noble, so worthy of good care and attention, are lessened, the knowledge of their increased comfort will amply repay the trouble involved, and the mission undertaken will be crowned with success. Read this book carefully, follow the directions plainly given, and the result cannot be otherwise than successful. 


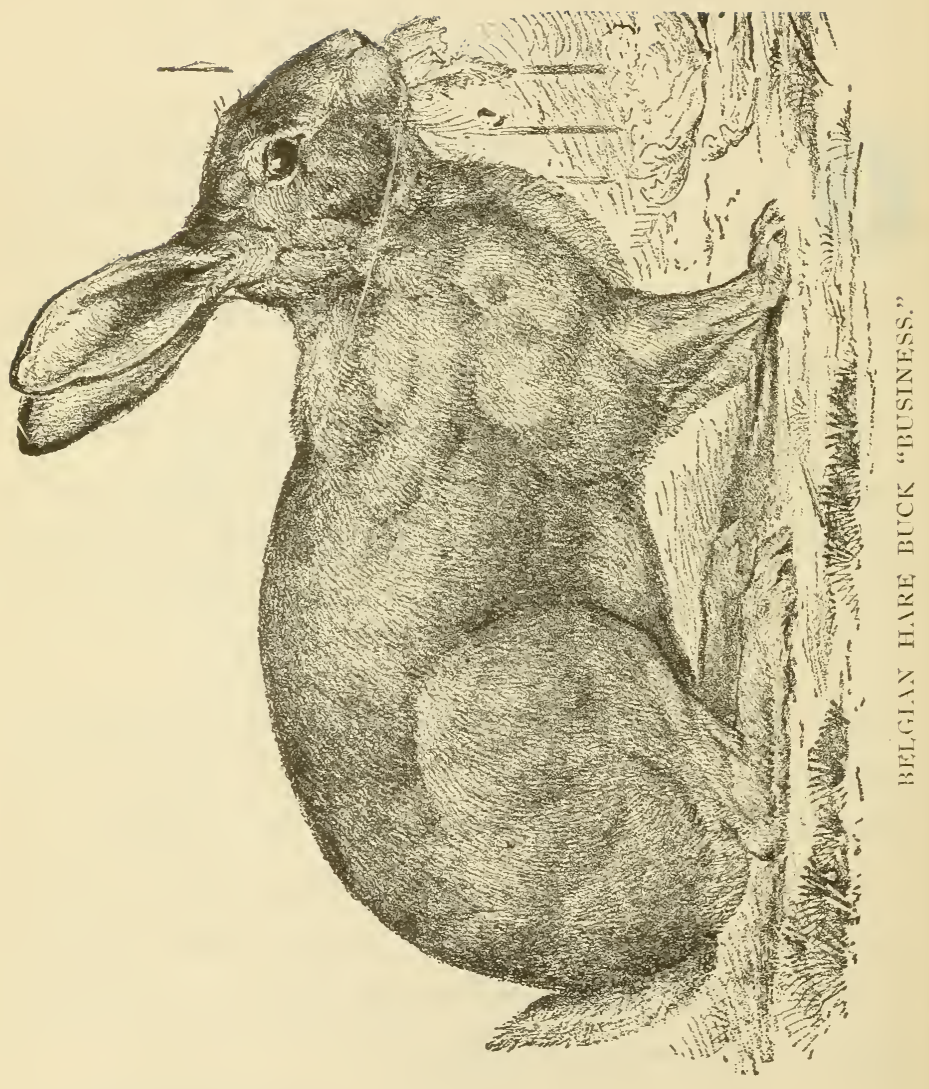




\section{THE RABBIT,}

\section{RABBITS FOR PROFIT}

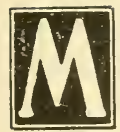

OST people in this country think that the rabbit is a useless pet, and being unacquainted with their habits and possibilities, condemn them, as unworthy of the care and attention they so justly deserve.

The Rabbit question has its bright side. The formerly neglected rabbit is now furnishing both pleasure and profit when managed intelligently.

I find that nine of ten fanciers who give up, do so becaus: they cannot keep their pets in proper health. Thare is a great deal in feeding, housing and mating.

The conclusion is, that fanciers spend too much money in feeding their Rabbits, giving them too much to eat, and the consequence is, that they either become diseased or there is a tremendous waste of food. As a rule they are kept in too small quarters, thereby generating disease for want of pure air. I am pleased to say that many men in the fancy have seen their mistakes and are now making the Rabbit a success financially.

There are Rabbits of all colors, sizes and conditions from which to select an ideal, which must possess many good qualities, among which must be a good appearance, large size, prolificacy, and hardiness; they must mature quickly, be exempt from disease and vermin, finally furnishing a delicacy for the table at a cost not exceeding their more popular rivals, poultry. 


\section{THE RABBITRY}

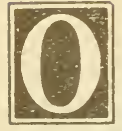

NE great essential to success is proper quarters for the stock. This building is called the rabbitry and is as easily constructed as an ordinary hennery and, for number of occupants to be considered, at a much less expense. The model rabbitry will afford protection from moisture and storm, space for exercise and separation of the breeders, and all important will be ventilation, for during the warm months sickness will be sure to follow any lack of pure, fresh air; plenty of windows, wide open, a large ventilator through the roof, all tend to keep the place cool and free from unpleasant odors; secure a tight roof and a dry floor preferably of cement; bricks absorb too much moisture and render the rabbitry very damp in cold weather; a good board floor is quite acceptable if cement is not to be had; regarding the hutches, there can be no mistake that the larger the better.

A breeding hutch should be not less than six feet long, two feet wide, and twenty inches high, partioning off about twenty inches of one end of the nesting room; this apartment should be dark, with an entrance six inches wide at the front and extending from the bottom to the top of the hutch, thereby ventilating the apartment. A door eight or ten inches wide of the same height furnished with a suitable catch for the front, so as to admit a whitewash brush easily. The front of the remaining forty inches should have a door of one inch mesh wire netting, fastened to a framework of seven-eighths by two inch wood, this door to be hinged at the end farthest away from the nesting apartment; the one inch mesh netting keeps in the young rabbits and keeps out old rats. If the partition between the living and nesting apartments is made so as to be easily taken out the hutch can be used by the growing brood until large enough to sepa- 
rate; always put the netting on the inside of the frame, for often bunny will enjoy nibbling at the soft wood generally used. I sometimes put a small piece of wood in the hutch for them to wear down their teeth by gnawing upon it. A brood buck will be perfectly happy in a hutch five feet long and of course needs no nesting apartment. The hutches are best built two feet from the floor, leaving that space for growing stock to run about in, for if you want those long racy specimens the standard demands they must have exercise and plenty of room to grow.

The food and water dishes must be securely fastened in place or the contents will be upset and wasted.

\section{FEEDING}

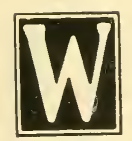

HAT will a Rabbit eat? It would be easier to name what they would not eat. Hay, oats, corn, wheat, peas, barley, and in fact anything that a cow or sheep will; cabbage, beets, turnips, carrots, dandelions, milkweed, plantain are a few delicacies; dry bread and milk, corn bread, boiled potatoes, raw onions, pea pods, green corn, and fresh cut clover for a dessert. What else? Every vegetable known to man, except poison ivy and wild parsnip. The only thing required is a little judgment in the supply and the variety will be very acceptable.

Always have a supply of good clean hay and oats before them, give green stuff once or twice a day and only in quantities that will be eaten clean; in the summer large quantities of green food can be fed; our pets are delighted with the fresh, cool, succulent plants and the grain bill correspondingly decreases. A little care is needed to change from a dry grain diet to green food. The young juicy stuff freshly gathered has, on 
grain fed animals, a tendency to scour them, but after they become accustomed to the diet they can be supplied liberally. In giving green food to youngsters care should be especially exercised.

Always bear in mind that the fresher the better. Trouble is caused by wet stuff being allowed to lie in a heap, thereby steaming and sweating until unfit for use, at the same time aroid wet green food if fresh and dry food is procurable. Remember that a heap of green stuff in the hutch to be trodden upon and covered with filth, is to my idea an unpardonable condition of affairs and is often the cause of serious trouble. Does nursing should have as much as they can eat, green corn, carrots, fresh clover, etc., are excellent milk producers and should be fed in conjunction with sound whole oats; give cool fresh water twice a day, keeping it always before them.

\section{WATER FOR RABBITS}

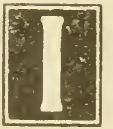

T IS pleasing to know that there is no greater advocate than myself in favor of giving rabbits water as a beverage. I was taught that water was to be used only as a remedy for diarrhoea, and, until recently, employed it only as such; but seeing my pets drink their own urine, I concluded they were thirsty and desired a drink of water. Think of the number of rabbits that are confined in generally too small quarters that have to suffer through the hot summer months and the feverish hours attendant upon giving birth to their young, deprived of the costless yet essential requisite, "a drink of riater." To the adherents of the no-water system, I would advise the reading of this clipping concerning 
the rabbit pest in Australia and how their extinction is conducted:

"In all but the remote sections, the rabbits are fairly under" control. Millions of rabbits have been killed by fencing in the water holes and dams during the dry season, whereby they die of thirst, and they lie in piles against the obstructions they so frantically and vainly try to climb."-Mr. S. Dickinson, in Station Life, Australia.

This, I think, should convince the most skeptical that water is beneficial, if not indispensable to a rabbit, particularly when in captivity and deprived of their natural juicy food. I will state that since adopting the water plan I have not had a sick rabbit in my rabbitry.

\section{MATING}

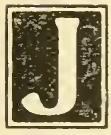

UDICIOUS mating is an essential to success in rearing any stock. Injudicious crossings are often resorted to, which result in no benefit.

The most common crosses met with are the Lop, the Flemish and the Patagonian; each cross showing distinctively its ancestors. The Lop is distinguished by its soft, pendulous ears; the Flemish by its grey color and large dewlap; while the Patagonian gives a rough coat and ears that are slung most any way from the proper position. These crosses all give excessive weight and are employed for that purpose when breeding for market purposes. In mating, whatever is done, we ought to bear in mind that we are not making a variety, but are trying to excel in the quality of a specimen of the present variety.

When we have excellent specimens from the best blood procurable, we should use our own stock for mating, utilizing the best of each litter, gradually building up a strain fit to win in 
any company. Having a type in our mind, and mating for that type, we can quickly succeed in securing an ideal for the market or for exhibition. Many fanciers erroneously place all their confidence in the buck. The breeder who insists on a good doe with a good buck is the winner. Rather a good doe than buck when only one is available; so go in for a good doe, and when you have her do not breed her to death, nor underfeed her when with a litter of young. The greatest difficulty is in the selection of colors. Other properties being equal in male and female, you must strike a balance-you must take light and the dark. Don't mate two of the same shade unless they have a certain qualification you do not otherwise possess. Try to mate one deficient with one fully developed in that deficiency; that is striking a balance, always taking care not to lose what has been obtained by previous matings.

\section{BREEDING}

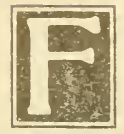

OR those who breed for profit there are two courses open-one is to keep all the stock until fit for exhibition, or for sale at fancy figures; the other is to market at from four to six months of age. In either case the methods are so similar as to not require any special explanations.

The doe has visited the buck and is placed in the hutch where she is expected to rear her prospective family, which is expected in thirty days from the date of the visit to the buck. She must be supplied with an extra amount of food and green stuff, and a couple of days before the time is up, give an extra quantity of hay and straw to build her nest with; leave no loose dishes or other articles in the hutch, for she may utilize them when building. 
It should be observed that during the whole period of pregnancy the doe should be kept as quiet as possible. Be sure and have a supply of water in the hutch at the time of kindling; this is very important and no doubt it prevents many does from destroying their young as soon as born. At this time there seems to be an unusual thirst, and in their frenzy they destroy their young to appease their inordinate thirst. Confirmed killers have been completely cured by the observance of this rule. Young does sometimes kill their first litter or neglect them, but this is not liable to occur again; do not condemn them too soon.

Do not molest the nest for two or three days, when, after carefully removing the doe from the hutch, giving her a run on the rabbitry floor, you may examine the young at your leisure, removing any dead or extra youngsters you do not care to raise-five or six are enough. Do not handle them more than is necessary. Give the doe a carrot or some dainty she will eat; after an hour or two replace her in the hutch, and she will be so anxious to nurse that the intrusion is seldom noticed. Feed her as usual, giving an extra quantity of food and green stuff, for the young grow fast, and if the doe is not well cared for she in turn cannot do justice to her young, and they will have slobbers if not sufficiently nourished.

In two or three weeks the young will be moving about the hutch; from now until weaned is the critical time in their existence. With the food and care recommended they will prosper. When about two months old they should be taken from the doe and allowed to run on the rabbitry floor; the doe being started for another family. In cold weather a nest box is good for the young litter; place it in a corner so that in their gambols they are not liable to run against it. A large soap box with the top taken off and a hole five inches square in the end answers very well. In the summer such a nest would cause bad ears from the excessive heat. Feed them hay, whole oats, stale bread, cooked potatoes, etc., a limited supply of green 
food and fresh water every day; bread and milk not sloppy is an excellent food for growing youngsters.

Separate the sexes when taken from the doe, and at four months of age separate the males, as they get quarrelsome and the weaker ones are completely ruined sometimes in their fights. Do not breed a doe under seven months of age, and not over four times a year; by this arrangement she will raise strong, healthy litters until four or five years of age. For breeding purposes an old buck and a young doe beget the largest young.

\section{THE NURSE DOE}

Is often employed in assisting the more valuable varieties to raise all their progeny. The plan followed is simple and effective. A Dutch doe makes the best nurse. They are struck by an inferior buck at the same time as the more valuable doe, so that when the exchange is made the nurse doe's young are all destroyed, and she is given half of the young from the other doe. Exercise the same care in handling. They are wonderful milkers, often rearing larger young than the larger doe.

Help the nursing doe all you can; she is the prime factor of your success, by giving the youngsters a start. Bread and milk is excellent food for her and the young. 


\section{KEEP A RECORD}

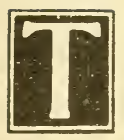

HE general plan of the record is simple in detail and effectual in its results. The great thing is system, which must be vigorously followed or disagreeable mistakes will occur, generally too late for reparation.

I keep a record book of my rabbitry, in which is recorded every incident concerning its occupants. Aside from the entries from time to time of the ordinary $D r$. and $C r$. items and occurrences of unusual importance, I have a record of every animal, its pedigree, mating and its final disposition, and can at a glance give any information required. The accompanying tabulations are actual copies of my record book in use at the present time.

When a rabbit becomes of an age sufficient for breeding, sh. is given a number and a name, the number follows conseca. tively, regardless of sex, and are recorded thus:

\begin{tabular}{|c|c|c|c|c|c|c|}
\hline No. & sex & loe & liuck & Born & Name & Remarks \\
\hline $\begin{array}{l}11 \\
1: 3 \\
18\end{array}$ & $\begin{array}{l}\text { Bk. } \\
\text { Do. }\end{array}$ & Imptd & $\begin{array}{l}\text { Imptd } \\
\text { Inpitd }\end{array}$ & $\begin{array}{l}\text { 1)ec. } 92 \\
\text { Mar. } 95 \\
\text { June } 9: 3\end{array}$ & $\begin{array}{c}\text { Business } \\
\text { Cinch } \\
\text { lureka }\end{array}$ & $\begin{array}{l}\text { First World's Fair. ()ct. 189:3 } \\
\text { Sold ()etober 1. 189:3 } \\
\ldots \ldots \ldots \ldots \ldots \ldots \ldots \ldots \ldots \ldots \ldots \ldots\end{array}$ \\
\hline
\end{tabular}

If a doe, she is placed in a hutch and a card is attached, showing her name and number. The bucks are not recorded unless sold or selected for breeding. When the doe has visited the buck another card is attached to the hutch, which shows the date, number, etc., viz: 
O.

Doe 18

Buck 20

1)ec. 5,1893

Due.Jan. 3,1894

F.
The large letter $\mathrm{F}$ at the bottom of the card is the mating check letter in the Record Book, and by looking at the mating $F$ the comparison is easily made. The records of matings are made thus:

\section{MATINGS}

\begin{tabular}{|c|c|c|c|c|c|c|}
\hline Letter & Doe & Buck & Date & Tested & Due & Remarks \\
\hline $\begin{array}{l}\mathrm{E} \\
\mathrm{F}\end{array}$ & $\begin{array}{l}10 \\
18 \\
19\end{array}$ & $\begin{array}{l}11 \\
20 \\
11\end{array}$ & $\begin{array}{l}\text { Nov. } 27 \\
\text { Dec. } 3 \\
\text { Jan. } 30\end{array}$ & $\begin{array}{c}\text { No. } \\
\text { Dec. 15 } \\
\text { Jan. } 30\end{array}$ & $\begin{array}{l}.1 \mathrm{an} .2 \\
\text { Feb. } 14\end{array}$ & $\begin{array}{l}\text { Sold lnecember } 1 \\
\text { IIad nine young, put } 5 \text { to nurse } \\
\text { Sold February } 5,1894\end{array}$ \\
\hline
\end{tabular}

The pedigrees are arranged thus:

No. 8. Doe, "Helderberg," Sept. 1892.

Sire, Imported Rufus $\mathrm{x}$ dam, Altomant.

She by Big Pete $\mathrm{x}$ Donovan doe.

Their parents imported in 1890.

\section{PREPARING FOR EXHIBITION}

Requires some extra labor, and more exercise for the specimens under preparation. The majority of rabbits are shown too fat; they must be worked down; they must be groomed daily; restrict the green food also; get them in that race-horse shape required in the exhibition specimen.

A buck which has become bunchy, no matter how he excels in other points, cannot enter the show with an equal chance with the long, slim built animal. The doe which has become baggy from excessive breeding is also handicapped. Immature specimens should not be shown, as they give the stranger an erroneous impression regarding their size, which is hard to eradicate. 


\section{DISEASES OF RABBITS}

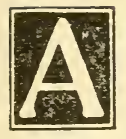

LTHOUGH a list, few are encountered by the American fancier, while the foreign fancier contends with many not enumerated here. Our climate and our abundance of everything that a rabbit will eat, together with our American fashion of not allowing ourselves to be tied down to the lines drawn by our grandfathers, all tend to make life much more bearable for our furry pets.

When you see your rabbit sitting and moping in a corner, paying no regard to his meals, etc., you may rest assured that he is not in good health, and you should immediately try and find out the reason and apply the remedy.

Let me impress upon your minds that in all cases "Prevention Is Better Than Cure," and if rabbits are kept in condition in well ventilated hutches, dry and warm, supplied with suitable food, they often go through their lives without having a single ill.

The prescribed treatment is founded on actual experience, and it is hoped that this article will enable the fancier to understand the various ills, and apply suitable remedies.

\section{APPETITE, LOSS OF}

Is due to various causes, generally a simple cold or its digestive organs may be disordered.

Treatment-Keep the rabbit warm and give a warm stimulant to drink such as mulled ale, or a little sweet wine, tempt with some delicacy such as a piece of carrot, bread and milk, steamed corn, with a few tea leaves mixed in; if in the summer give a little dandelion daily. 


\section{BLINDNESS IN THE YOUNG}

Can often be traced to filthy hutches or some projecting nail or wire. When the hutches are neglected the filth develops noxious gases and tends to inflame their eyes, often causing total blindness; they appear swollen and often red pimples are to be seen around the lids.

Treatment-Isolate the rabbit, taking care that the hutch is warm. Bathe the eyes with a lotion of $1 / 4 \mathrm{oz}$. of sulphate of zinc to a pint of water, apply two or three times a day with a soft sponge.

\section{CANKER}

In the ear is a very uncommon disease and one quite difficult to cure. The symptoms are a thick yellow discharge from the inside of the ears and sometimes from the eyes also.

Treatment-Clean out the ear with a small soft sponge fastened to a stick soaked in warm water, wiped dry carefully and wash out with the zinc lotion, twice a day, cleanse the animal's bowels with cabbage leaves or a small dose of flowers of sulphur in its food.

\section{COLIC}

Is a painful contraction of the bowels due to indigestion or from constipation, the animal is restless and the belly seems to be more or less distended with wind.

Treatment-Dissolve a Beecham's pill in water, say two teaspoonfuls, give half a dose once a day until the bowels act freely, feed carefully for a few days, giving little green stuff.

\section{CONSTIPATION}

Is not generally difficult to cure; it is caused by an excess of food. The rabbit is seen to mope in the corner of the hutch and refuses to eat, yet seems often very thirsty. 
Treatment-Give the pill solution until the bowels move freely, feed bread and milk or green food, being careful not to cause the other extreme.

\section{DIARRHOEA}

The passage of loose watery stools more frequently than is natural constitutes diarrhoea, and may result from several causes such as a chill, excessive heat, a fright or a too liberal supply of green food when unaccustomed to it.

Treatment-Remove the rabbit to a warm, dry hutch, and take an ordinary dose (for a grown person) of any favorite "cholera cure," add to one teaspoonful twelve or fifteen teaspoonfuls of water, mix well, give the affected animal a teaspoonful every three hours until an improvement is noticeable. Supply with dry oats, bread or clover hay, allow a little milk or water, but no green food until recovery is assured.

An over supply of succulent food to young growing stock is often the cause of

\section{DROPSY}

The belly becomes swollen and hard and for a time does not seem to seriously affect them, but soon they lose their relish for food and if not relieved will gradually pine away and die.

Treatment-Remove to a large, airy hutch where they may have more exercise, or let them run on the rabbitry floor, feed them dry bread, oats, cracked peas; hay (not clover), water once a day, and occasionally a carrot or turnip, rigidly excluding the green food until health is regained.

\section{EAR GUM}

The ears should be occasionally examined. to see if they are free from dirt and wax; when suffering from this trouble they shrink from being handled, as it no doubt is painful to them. 
Treatment-Syringe the ear carefully with warm water and glycerine, care being taken not to inject too forcibly, dry with a soft sponge and apply some simple ointment daily, avoid handling by the ears at all times, as heavy specimens are often seriously injured by so doing, causing serious inflammatory conditions so difficult to eradicate.

\section{FITS}

Or convulsions are most commonly met with in young stock, and generally can be traced to some irritating cause, such as indigestion or over-feeding.

Treatment-Keep the affected rabbit warm and dry, and give the following pill: Sulphate of iron 1 grain, extract of gentian 2 grains, to make one pill. One to be given twice daily. Give plenty of good nourishing food and exercise.

\section{SORE HOCK}

Is generally caused by filthy hutches, dampness, and sticks or slivers in their litter; those who use sawdust or machine shavings for litter can easily trace the cause of their troubles; improper feeding will debilitate and lower the vitality necessary to heal the wounds inflicted by their stamping, while the damp filth will prove a continuous irritant.

Treatment-First clean the hutch thoroughly, then whitewash, provide a good bed of hay or oat straw, wash the affected parts in warm water, dry thoroughly, apply carbolized vaseline in an aggravated case put on a bandage, being sure to sew it on, not leaving any ends for the animal to nibble on. Give good wholesome food and water or bread and milk.

\section{INSECTS}

Are generally traced to neglect.

Treatment-Is simply cleanliness and sanitation. Carbolized whitewash is recommended. 


\section{MANGE}

Is caused by a parasite which burrows in the skin and is analogous to the itch in man. Sulphur is considered a specific in man, so it must follow the same in the rabbit.

Treatment-Isolate the rabbit and apply the following ointment: Flowers of sulphur $1 \mathrm{oz}$., lard $4 \mathrm{oz}$., mix. I have been unusually successful in treating mange in dogs, cats and rabbits with carbolized vaseline. The animal does not lick it off as they will the sulphur mixture and it is certainly much easier applied. In every case thoroughly cleanse the hutch containing the affected animal.

\section{PARALYSIS}

This disease generally attacks the hind quarters and renders them quite useless. The cause is generally traced to uncleanliness and damp floors.

Treatment-Keep the rabbit warm and furnish nutritious food; also remove all filth in the hutch and disinfect thoroughly; give twice a day a pill as follows: Tartrate of iron 20 grains, quinine 10 grains, extract of gentian 20 grains; mix, make into 10 pills.

\section{RED WATER}

Or as is often called bloody urine, is an affection of the kidneys and has no general symptoms except as stated, and if allowed to go on will cause a rapid decline and end fatally.

Treatment-Care in food, fresh air and a warm, even temperature. Give 10 drops of the following twice a day in water: Sulphuric ether $1 / 2 \mathrm{oz}$, tinct. gentian $1 / 2 \mathrm{oz}$, tinct. ginger $\mathrm{T} / 2 \mathrm{oz}$. Mix. 


\section{SNUFFLES OR INFLUENZA}

In the English breeder's hutches, snuffles is almost always present and is invariably fatal if not promptly attended to; the American fancier is often troubled with the disease, but it seldom is as virulent as our foreign friends find it. Just as a man neglects his own person when suffering from a cold, so is the person apt to neglect the rabbits. But a cold is always a matter of concern in a rabbit, and should receive immediate attention. The symptoms of snuffles are sneezing, moist nostrils, which in a few days become thick and filthy, refusal of food and its coat becomes rough and disordered, giving every sign of illness and discomfort.

Treatment-Wash the nose and mouth well with carbolic soap, also the fore legs and feet two or three times a day, wipe dry and put an extra quantity of fine hay in the hutch, keep in a cool, airy place and feed stimulating foods. Where this course does not effect a cure, the following favorite English prescription is recommended, which must be used in an ordinary vaporizer: Fill the vaporizer about two-thirds full of boiling water, into this pour $1 / 2$ oz. of soluble sanitas oil, 1 teaspoonful of oil of eucalyptus and 10 drops oil of camphor, place the top on and light the lamp underneath. Place the rabbit in a small hutch, covering up with old sacks to prevent the escape of the steam. Insert the spout of the vaporizer into the lower part of the hutch allowing the steam to enter. By this treatment it is intended to have the medicated vapor reach the affected membranes by inhalation. Treat in this manner for ten or fifteen minutes, care being taken that the invalid is not suffocated by the operation; after treatment leave the rabbit in the hutch for a half hour, then remove as previously advised. It is said that three operations generally effect a cure. In severe cases three drops of eucalyptus and glycerine in equal parts, given in a spoonful of milk for a few days, is recommended. 


\section{VENT DISEASE}

Occurs in does and is traceable to improper pairing. It is very troublesome to cure, but if taken early and attended to patiently a cure is usually effected in a few days.

Treatment-Isolate the affected rabbit and apply carbolized vaseline twice a day, rubbing it well into the affected parts. Do not mate until entirely cured, as the trouble can be spread indefinitely by a brood buck.

In conclusion I wish to bring to notice and in almost every case the trouble can be prevented, as has been stated previously we have reason to be thankful that so few of these diseases are found in this country. But that fact does not secure immunity. We must be cautious in feeding, secure ventilation without draughts, and enforce a rigid regime of cleanliness, if we wish to go through the hot summer months with the health of our pets unimpaired. Build up your does weakened from excessive breeding by allowing a rest in summer. You will have just as many rabbits next January, by so doing, and I assure you that you will have fewer dead and stronger living ones. 


\section{THE SEVERAL VARIETIES OF RABBITS}

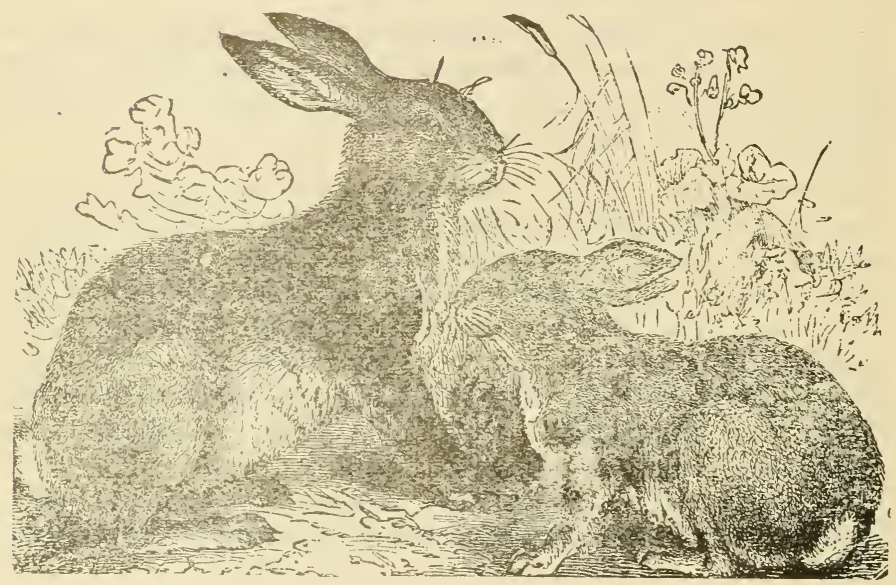

THE BELGIAN HARE RABBIT.

The Belgian Hare RabBit is said to have originated in Belgium, where they are now found small in size, but grand in color and markings. They are also found in France, Flanders and Germany in various stages of imperfection. They are called Belgian Hares simply on account of their resemblance to the hare.

It was for a long time supposed that this valuable rabbit was a cross between the hare and the rabbit. This is not so, and all attempts to produce the hybrid have either resulted in a failure or the production of a sterile mule. The habits of the hare differ so materially from those of the rabbit that the crossing is effected with great difficulty. 
„e The hare is born fully developed with eyes open, and can run about and eat almost immediately; while the rabbit comes into the world blind, naked and helpless, and does not venture from the nest until from two to three weeks of age. The hare nests on the ground, in some sheltered location, never burrowing; while the rabbit always burrows in the wild state and will when in captivity, if allowed.

The Belgian of to-day shows the improvement attainable by judicious and systematic breeding; foremost in importance is their increased size and prolificacy. As the modern Belgian is distinctively a production of the English fancier, the English standard of excellence will be our guide in describing its characteristics as a distinct variety.

To properly describe the Belgian Hare is difficult, especially the color. "Rufus-red" is a reddish tan, clear and bright, showing the clearest on the top of the neck and fore shoulders of the animal. The ticking consists of each hair of the animal's coat being tipped with black, which, according to its density and distribution, its value is governod. The more mottled or wavy it appears, the more points are secured. Starting at the shoulders, the color shades darker back over the back and sides, showing the ticking in its finest markings; the haunches are of a gray shade, but showing a distinct brownish cast, they being usually well marked with a wavy ticking.

The head and ears have a dark shading, but no distinct ticking, it being so evenly distributed as not to be called ticked. The head is not large in proportion to the body; it is carried well up and graceful. The forehead is flat and very prominent over the eyes, giving them a very prominent appearance. The eyes are bold, round, and of a dark brown color, possessing a wonderfully pleasing and contented expression. The ears, about five inches long, set up firm, close together and leaning slightly back, having an edging of black over the tips and extending well down the edges. This edging is termed lacing and is characteristic of this variety. 
The fore feet and legs are small and delicate, and are kept well under the animal, are well colored and free from white.

The belly and the underside of the tail are white, preferably with a brownish cast.

The hind feet and legs are large, strong and powerful; while generally lighter in color than the fore feet, they must show no white on the outside or top; for the slightest white on the face, legs or body of a Belgian Hare is a disqualification.

Shape in the Belgian is, aside from color, the chief attraction in appearance, and it is difficult to secure and maintain. The Belgian should be long and slim in build, long and fine in bone, narrow in front, long and lean in the head-in fact, a rabbit calculated to give the observer the impression of speed. The length characteristic to be accompanied with a corresponding gracefulness and symmetry of form. The angular, gawky, stumpy, or mule-like forms being decidedly objectionable.

The English standard for weight is about eight pounds, which could, in this more favorable climate be made more, say nine pounds, without sacrificing other valuable points. Specimens are occasionally shown weighing from ten to eleven pounds. No objection should be made to this excessive weight, provided, however, their characteristics are maintained. As a rule, the heavy specimens are very faulty in color and form, also often possessing a well developed dewlap. Coarse, heavy head and ears, bad feet and stumpy forms are too often seen in these elephantine specimens. Belgians should not have a dewlap and the exhibition specimen is cut five points when possessing such an appendage.

Belgians, though not so showy as some of the smaller breeds, by reason of their self-color, are noble looking animals, and for domestic use are of greater value than any of their companions. They are hardy, and few are born that will not with ordinary 
care and attention be reared to maturity. They are usually prolific, producing from six to ten young at a litter, and will breed from six to eight times a year. They are very docile, much more so than the smaller varieties, and do not consume as much food as is expected for their size.

Of all domestic breeds the flesh of the Belgian tastes the most like the hare, and has not the rank flavor so common in the ordinary rabbit. They will live and thrive in woods or warrens, when turned down for breeding at six or eight months old, if some protection be given them from the inclemencies of our seasons.

THE ENGLISH STANDARD FOR THE BELGIAN HARE.

1. Color-Rich rufus red (not dark, smudgy color) carried well down sides and hind quarters, and as little white under the jaws as possible............ 20

2. Ticking-Rather wavy appearance and plentiful.... 15

3. Shape-Body long, thin, well tucked-up flank and well ribbed up; back slightly arched; loins well rounded, not choppy; head rather lengthy; muscular chest; tail straight, not wry, and altogether of a racy appearance 20

t. Ears-About five inches long, thin, well laced on tips and as far down outside edges as possible; good color inside and outside and well set on ........... 10

5. Eyes-Hazel color, large, round, bright and bold..... 10

6. Legs and Feet-Forefeet and legs long, straight, slender, well colored and free from white bars; hindfeet as well colored as possible.................. 
7. Size-About eight pounds.............. 5

8. Condition-Not fat, but flesh firm like a racehorse, and good quality of fur............... 5

9. Without dewlap................... 5

Total....................... 100

Bi.Ack Belgians.-Breeders of. Belgian Hares frequently are surprised by the advent of one or two black young ones in a litter and often they hasten to destroy the stock as impure. The following article taken from the leading English authority on Belgians will I think clear away the doubt to many.

"The value of Black Belgian Hares for stud purposes is very imperfectly understood. As you are aware, the old breeders make very successful use of them, as Black is part of the color of a Belgian, at times they are likely to throw a black. For many reasons they are invaluable; they are useful to mate to does lacking tone and too light in color; they also infuse new vigor in their offspring; they are always the most healthy, the strongest and the most precocious of the litter. But why are they black? In making the Belgian a Belgian, black blood was introduced for just the purpose stated, and now that nature having all its force and energy concentrated, the revision is accounted for.

The Lop-Eared Rabit, until recently, was the most popular of the fancy varieties, the peculiar formation of its ears being its chief attraction. They have enormous drooping ears, often measuring twenty-two or more inches from tip to tip, and are often over six inches in width, this ear development being of the greatest importance in the breeder's mind. They have 


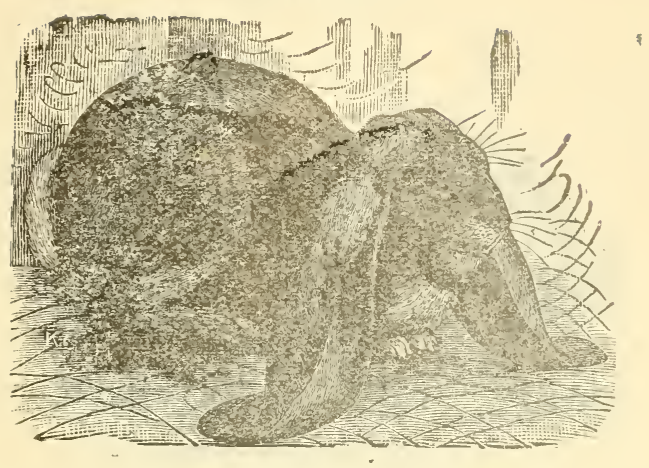

not yet become popular in this country, probably on account of requiring so much attention and care, they have become by years of breeding a hot house variety. The hutch must be kept warm, and in the cooler months artificial heat must be supplied. The Lop generally possesses a large dewlap, which is not an objection, other points over-balancing.

In self-colors they are found black, grey, white, blue, fawn and yellow. In broken colors, combinations of white with any of the above, and even a mixture of black, fawn and white are found, making the tortoise shell.

Lops often weigh from sixteen to seventeen pounds, and even eighteen pounds is recorded.

The Siberian Rabbit in perfection should resemble both the Himalayan and the Angora, having the Himalayan marking and the Angora's fleece. Most specimens shown are but crosses of the two varieties.

The Dutch Rabit, though much smaller yet none the less popular, is a comparative stranger in this country. They are very pretty and useful; the size is bred down by the exacting fancier, their weight being limited to five or six pounds. Their ears are just the reverse of the Lop, standing erect and 


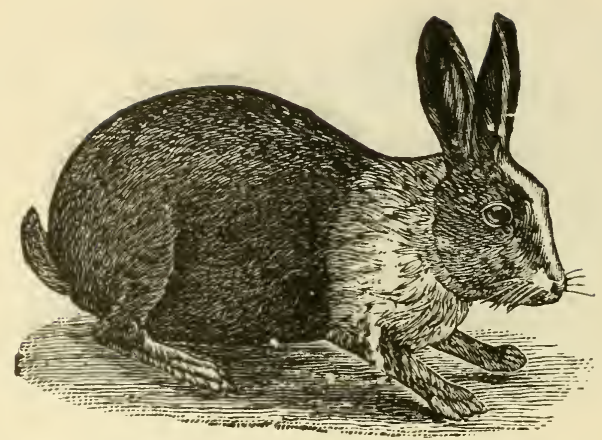

being quite short. They are usually prolific and hardy and will breed eight or ten times a year, raising eight or ten young at a litter. On account of their wonderful milking proclivities they are selected as nurse does where more valuable stock is to be raised. In colors they range over the same as the Lops and have a characteristic marking of white in the shape of a broad band or collar around the body at the shoulders and a white blaze in the face; in the old style this collar being much larger than in the new style which covers only the neck and forward toes.

The Egyptian Rabbit is a new comer, resembling the Himalayan so closely that the assertion that they were of no relation was received with doubt. They weigh from eight to ten pounds and are hardy and prolific. The body is white with black ears, nose, feet and tail; it has also a black ring around each eye and a black stripe extending along the back. Where first brought to notice in France, they are said to be a superior article of food, fully equaling any of its competitors. 


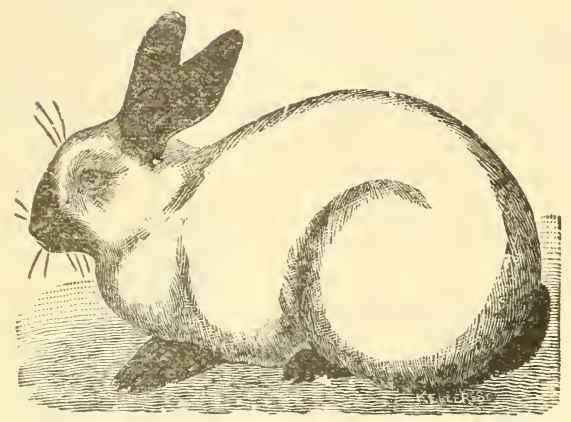

The Himalayan bids strong for popularity on account of its beautiful markings. The body is white and the fur short and fine, while the ears, nose, feet and tail are dark nut brown, almost black; the eyes are red, the ears are very short and firm. They weigh from five to seven pounds and are extremely hardy and quite prolific.

The Silver-Gray Rabbit originally was a near neighbo: to the Himalayan, and has become a favorite in Europe and England. They have improved wonderfully in appearance since their introduction. In color they run from a bluishbrown through the slates to a black under color. The ideal rabbit being a dark blue under color and well silvered, with white hairs tipped with black. They are good breeders and are hardy, growing to a good size, often weighing ten pounds at maturity. 'The Creams and Fawns are offshoots from the Silver Grays, and are probably bred and sold as such. They share the popularity their ancestors enjoyed and are with them the fanciers' choice in England at present.

The Japanese Rabbit appeared simultaneously with the Egyptian and is thought to be allied to the Dutch, though claimed to be a distinct variety. Some shown in Paris in 1888 were of the true tortoise-shell color, which is black, brown and 
orange-no white as in the Lop or Dutch markings. The head and ears were beautifully striped, as were the feet. The specimens shown weighed about ten pounds each and were said to compare favorably with the other breeds in hardiness and prolificacy.

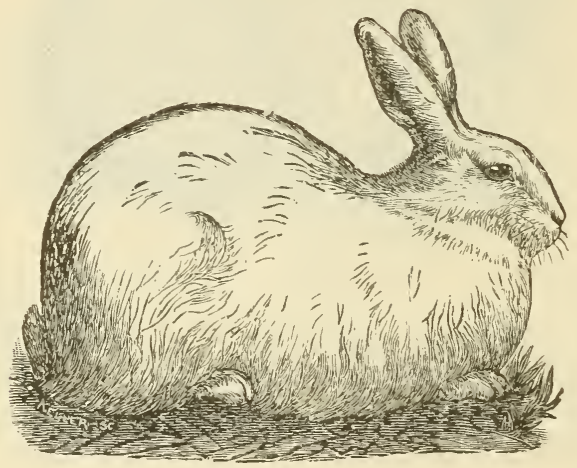

The Angora Rabbit is decidedly popular wherever bred; they occupy a distinct place in the fancy as a freak of nature that is at once ornamental and useful. The coat of the Angora is its chief attraction, being composed of long, fine, fleecy wool, making them appear to be of prodigious size, when in reality they are no heavier than the larger specimens of the Dutch. The most valuable are the white with pink eyes, although colored ones are frequently selected. They are good breeders and attentive mothers. Especial care must be taken to keep the hutch clean and well supplied with clean hay or straw, and their fleeces kept free from knots and filth.

The Polish Rabits is pure white, thin pink ears, colorless eyes, and altogether a delicate, timid animal. They are said to have originally been found in Poland, but every investigation seems to prove that they are but Albinos, inbred until all 
vitality and hardiness has been bred out. They are indifferent breeders and inattentive mothers and can only be placed as pets.

The Flemish Giant Rabbit, aside from the Belgian Hare, is the most popular of the large breeds. It is claimed by some that the Flemish is an overgrown Belgian which by continued selection and breeding has resulted in the present variety. If this be so, they are far removed, for the Flemish is characteristically a distinct variety. One will meet more BelgianFlemish crosses than pure blood of either variety. The Flemish

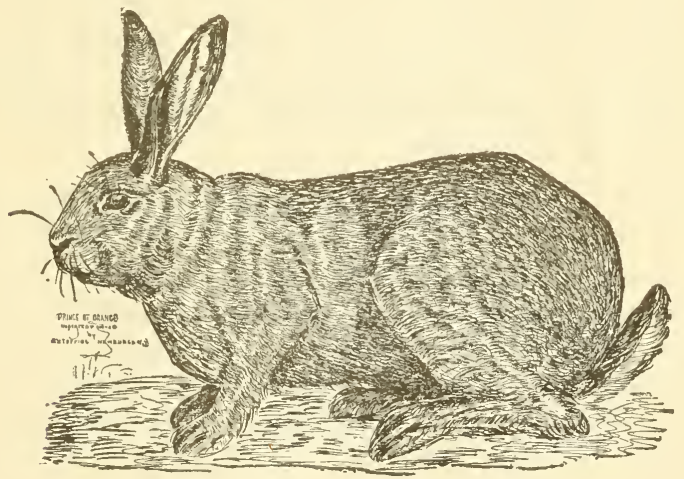

stands the only rival to the Belgian and is far behind in popularity at present. The Flemish Giant weighs from twelve to fifteen pounds, and in color is a dark steel-gray; ears about six inches long, carried erect. This variety possesses a large dewlap; eyes dark brown; bulldog shoulders, and massive hind quarters; they are fair breeders and are quite prolific and hardy.

The English Rabit, while comparatively unknown here, is very popular with the English fancier. They are peculiarly marked, reminding one of the coach dog-white with black spots. The most valuable arrangement of spots are one on, 
or one each side of the nose, a ring around each eye, black ears and tail, black patches along the back and sides, gradually increasing in size from the shoulders back over the body; the more symmetrically they are arranged the greater their value. This rabbit is essentially a fancy variety, and compares well with the other varieties for size and prolificacy.

The Patagonian Rabbit is the giant of the species, averaging from fourteen to fifteen pounds. Some authorities claim them to be an offshoot of the Belgian or the Flemish. The color is iron gray somewhat tawny, and rough coated; they have large, thick, heavy ears, the tips of which are soft and pendulous; usually they are carried standing out from the head like a letter $V$. In this variety are found several styles of lopear, namely: half-lop, horn-lop, and oar-lop, which are considered very objectionable.

The St. Hubert Rabiti is the lord of the fancy in France, where it originated; though only recently perfected, it has become very popular as a fancy and as a market rabbit. The French claim all the good qualities of the other varieties are to be found in the St. Hubert. They weigh from twelve to fifteen pounds and resemble the Belgian Hare in shape. In color, the body and ears are silver, the nose and belly white. They have two stripes of white across the back, the ears are laced like the Belgian Hare. The matings necessary to produce the St. Hubert are these:

Silver buck $x$ Belgian doe..........A

A x Wild Rabbit doe.............B

B x Flemish Giant doe........St. Hubert

Five or six years of mating and selecting have fixed the characteristics of this variety as a distinct breed.

The Ram Rabbit of Spain resembles the Patagonian, with the exception that the Ram possesses a dewlap. 
The Swan Rabit is similar except the ears, which are about two inches long. These last two varieties have not been accepted by fanciers yet, therefore our knowledge of them is limited.

Last, but not least, allow me to introduce the DEAD RABBIT. This genus is found all over the United States; they are easily recognized whenever encountered. Immediately upon a hardworking fancier securing a success in his fancy, these leeches assume all the responsibility and proclaim to the world that it was their stock (how modest!) which won the victory; they seize upon every occasion to flood the country with the grossest imitations of the genuine article, and when brought face to face with their outraged patrons flatly deny any intent to defraud. The Belgian Hare has not escaped these most ravenous of beasts. Care has been taken to exclude this variety from these pages, hoping the near future will find the Dead Rabbit known only in ancient history.

Respectfully yours, 


\title{
Raising Belgian Hares and Other Rabbits
}

\author{
By David E. LAUTz, Asst. Bureau of Biological Survey
}

(U. S. Department of Agriculture, Farmers' Bulletin No. 496)

\section{INTRODUCTION}

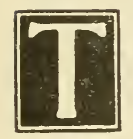

HE present bulletin is designed to answer briefly the many letters of inquiry received by the Department of. Agriculture, particularly by the Bureau of Biological Survey, relative to the breeding and management of Belgian hares and other domesticated rabbits. No originality is claimed for the subject matter. The principal facts in regard to the raising of rabbits are as well established as those relating to rearing the more important domestic animals, and the volume of directions needed is small. Once launched as a breeder, the amateur will accumulate experience day by day which will soon enable him to avoid gross mistakes in rabbit management.

\section{RABBI'TS AS FOOD}

In the United States wild rabbits have always been an important source of food, especially during the cold part of the year, and hence less attention has been paid to the breeding of rabbits than in most foreign countries. It would be impossible to estimate correctly the number of rabbits marketed and eaten in Great Britain. Not only are the home warrens and farms drawn upon for a supply, but from 10,000 to 12,000 tons are imported annually, coming partly from the Continent, but in greatest numbers from Australia and New Zealand.

In France, Holland, and Belgium rabbits are a common article of diet and rabbit breeding is general on farms, especially where the land holdings are small. Spain produces many 
domestic rabbits and is sometimes regarded as the original home of the common European rabbit (Lepus cuniculus), since Strabo, writing about the beginning of the Christian era, stated that ship cargoes of rabbits were brought to the Roman markets from that country. Whether or not the European rabbit is superior as food to the wild cottontail rabbit of our forests and fields is a matter of individual taste. The so-called Belgian hare is merely a domesticated form of the wild rabbit of Europe, long bred with special reference to the development of a superior food animal. Its flesh is generally considered better than that of the ordinary hutch rabbit.

\section{HISTORY AND CHARACTERISTICS OF THE BELGIAN HARE}

\section{ORIGIN}

The Belgian hare probably originated in Belgium or northern France. It was quite generally known in the northern part of Continental Europe before the attention of English fanciers was directed to it. As their first stock came from Belgium, that country was credited with having originated the breed, which was exploited in England and elsewhere as being a cross between the rabbit and the wild hare (Lepus timidus).* This claim seems to have been fully disproved by many unsuccessful efforts to produce the same cross. The chief known reason for calling the animal a hare lies in its color resemblance to the wild hare.

\section{THE BELGIAN HARE IN AMERICA}

In the hands of English fanciers, the Belgian hare was greatly improved, and it is still a popular breed with them, although the

*J. Simpson, in The Wild Rabbit (London, 1895) states that the Belgian hare is such a hybrid, and that it was originated by a M. Roux, of Angouleme, France. 
fad for it never reached the acute stage shown later among American breeders. The animal was introduced into this country over 20 years ago, and within a few years its popularity became astounding. The finest show animals commanded

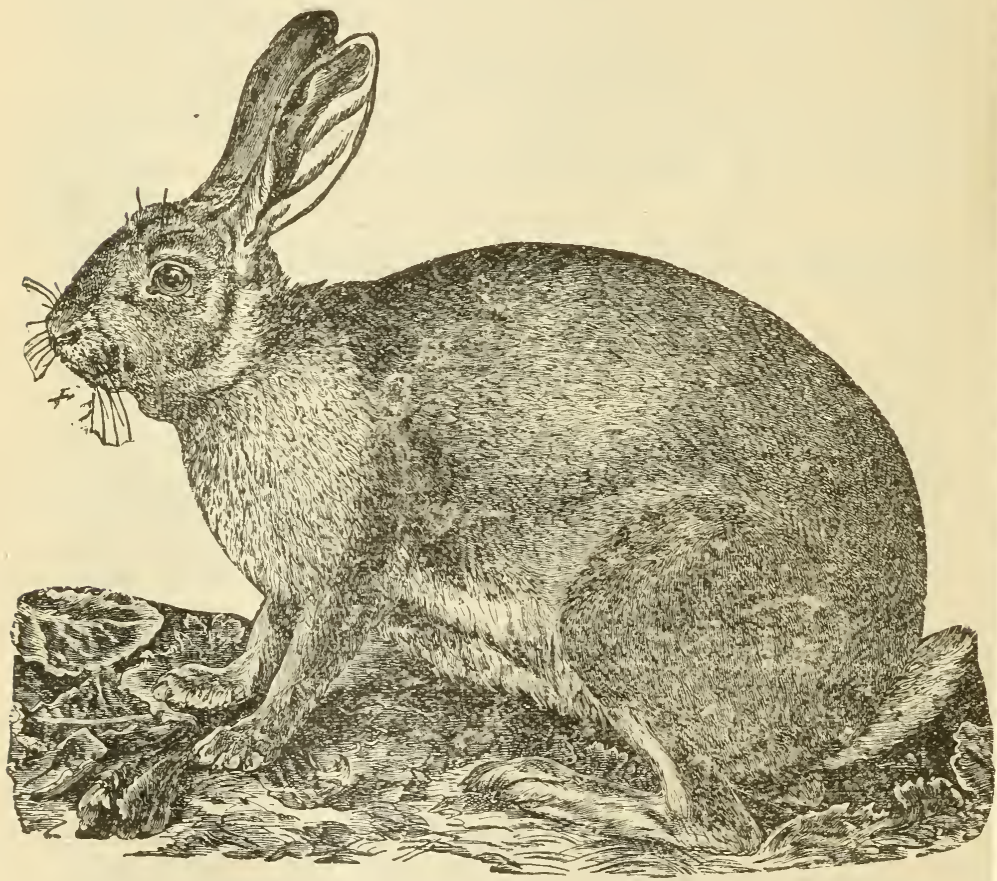

BEIATAN HARE.

enormous prices and extraordinary claims were made as to the excellence of the breed for the table. As was natural, when the reaction came and the public found out that the Belgian hare is a rabbit not much superior to other kinds, the animal was 
unjustly condemned and execrated. As a consequence, the whole business of breeding domestic rabbits in the United States has for the past few years been much neglected.

In spite of the setback caused by the collapse of the Belgianhair bubble, this breed has maintained a greater popularity than any other, and many breeders are still raising it. The Flemish giant, owing to its greater size, is preferred by some. The fact that rabbits are easily grown and are a cheap and excellent substitute for the ordinary meats is likely to turn the attention of many more persons to rearing the animals. That they can be propagated without costly investment in land and buildings is a peculiar advantage. Further, the presence on the farm of another animal which, like poultry, may be killed and prepared for the table entire and at short notice, is exceedingly desirable. All these circumstances make it extremely probable that the business of rearing rabbits will grow in importance. The tendency in this direction is evidenced by the increasing number of inquiries about the management of the animals received by the Department of Agriculture. The greater number of these relate to the Belgian hare.

\section{THE BELGIAN HARE AS FOOD}

The Belgian hare is one of the best rabbits for table use. It weighs more than most breeds, develops very rapidly, and the quality of the meat is superior to all the others. The Flemish giant is a Belgian hare bred exclusively for large size, but with the result that the meat is coarser and less delicate in flavor. These characteristics are regarded by some persons as desirable, but this is largely a matter of individual taste. Most people would prefer the white, finer-grained flesh of the original Belgian hare. It should be remarked, however, that much of the excellence of the rabbit as food depends upon its cooking. As often prepared, it is dry and insipid; while in the hands of an experienced cook it becomes all that the most fastidious taste can wish. An especial requirement in cooking the Belgian hare 
is that none of the natural juices of the meat be lost in the process.

\section{CARE OF OTHER BREEDS OF RABBITS}

The directions herein given for the care of Belgian rabbits are applicable to the management of most other breeds. The ordinary English rabbit, regarded as of less value as a food animal, is even more hardy and therefore needs less care. The lop-eared rabbits and possibly a few other breeds require artificially heated quarters in winter, but in other respects their management is the same as for the Belgians.

\section{SELECTION OF STOCK}

If one breeds rabbits for food only and not for show purposes, the selection of stock is of less importance. All that is required is a sizable animal of good, hardy stock. However, the points for which the fancier breeds the Belgian hare include also those most desirable in a food animal, so that if one can find stock with these characters well marked, and at the same time constitutionally sound, he should by all means obtain it. Purebred stock is more profitable, too, because it may be sold for breeding purposes as well as for the table.

Color.-Belgian hare fanciers of a few years ago differed somewhat in opinion as to the proper standard color for thi; animal. Some aimed at the color of the wild English hare-a sandy light brown. Most American breeders seem to have preferred a deeper reddish brown. In all other respects the standards were the same. The chief requisite concerning color is that it shall be as nearly uniform as possible throughout the upper surface of the animal and that the fur shall have a rich luster. The "ticking," or shading, should be wavy rather than dotted. The belly and lower surface of tail and hind feet should be whitish, but not pure white. The neck and breast 
are somewhat lighter in shade than the back, but not in marked contrast with it, nor should the change in shade be abrupt.

Ears. - The ears of the mature Belgian should be about 5 to $5 \mathrm{I} / 2$ inches in length, varying with the size of the specimen. They should be well shaped, strong at the base, and almost transparent at the middle. They must not be pendulous, but should, when the animal is quiet, be inclined backward, resting straight over the shoulders. A narrow black ending at the tip and as far down the front and back as possible marks the best specimens.

Body. - The body of the Belgian is longer in proportion to the whole bulk than that of any other breed of the same size. Bucks and the younger females should never have the appendage known as "dewlap." This sometimes develops in the older does, but is regarded as a blemish in animals intended for show purposes. The back should be only slightly arched and the forelegs and feet should be perfectly straight and free from white.

Age of breeding stock.-The beginner should always select mature animals about a year old for breeding stock. These may be known by the brisk, alert look, the small white teeth, and the small claws, almost hidden in the fur. Coarse, long claws are a sure indication of age. He should avoid listlesslooking, rough-coated, or pot-bellied animals (except pregnant does), and especially those having the whites of the eyes staine I with yellow. A hutch rabbit in good health is gentle, neithe. savage nor over timid, and does not scream when lifted by the ears.

The sexes.-The does selected for breeding may be of the same strain and even of the same litter, but the buck should be of different stock, and when possible obtained from another breeder. Hardy animals with the best characteristics of the breed may be bought at from $\$ 1$ to $\$ 2$ each. They may often 
be had of near-by breeders, and thus save the expense of carriage on long journeys by express.

\section{HUTCHES AND PENS}

The Belgian hare does not do well when kept wild in open warrens. The common English rabbit is better for this purpose. A good many Belgians have been turned out in various parts of the United States, and in the vicinity of the city of New York and on the western coast there have been some complaints of damage to crops by wild Belgian hares. As a rule, however, and fortunately for the farmer, these animals, when obliged to shift for themselves, fall an easy prey to their enemies and disappear within a few months.

Belgian hares may be successfully managed in two ways: (1) Entirely in hutches, or (2) in outdoor fenced runs, or courts, with hutches for does when having young, and sleeping hutches for other stock. The hutch system with various modifications is the more common, and is the only method adopted by rabbit fanciers who raise for show. The use of small runs or rabbit courts to give the animals healthful exercise in fine weather is of advantage.

\section{THE RABBITRY}

The rabbitry may occupy part or all of a barn or shed, or be built in a sheltered space in the angle between buildings $\because x$ walls. The indoor rabbitry has decided advantages. The place should be well ventilated, but not subject to draughts of cold or damp air. These may be prevented by ventilators in the roof, or by a system of elbowed pipes passing through the sides of the building and reaching a height of 2 or 3 feet above the openings. 


\section{HU'TCHES}

Hutches for the Belgian hare should be somewhat larger than those intended for smaller breeds. They should be built of good lumber, should have tight floors, and should have at least 12 square feet of floor space and a height of 2 feet. If there is plenty of room in the rabbitry it is best to have the hutches separate; but they are usually set in tiers or stacks, two or three in height. Each hutch in the rank is complete in itself, so that its position may be shifted at any time.

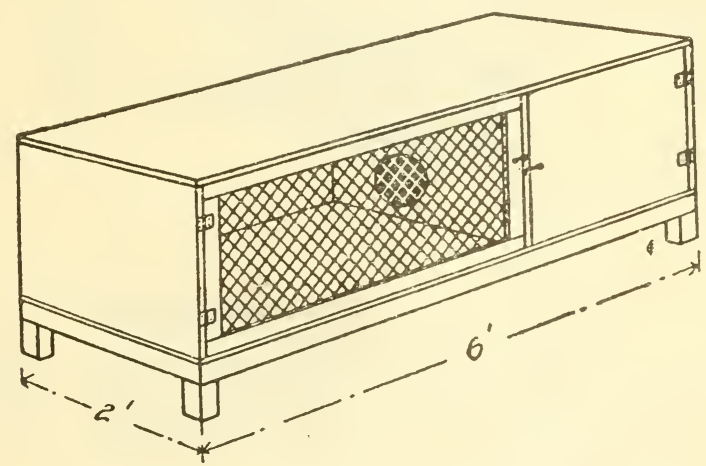

FIG. 1-A CONVENIEN'I R.IBBI'T IIU'TCII.

A convenient indoor hutch (Fig. 1) is one 6 by 2 by 2 feet, with a movable partition dividing off a third of the space at one end for a nest and sleeping chamber. The partition has $i$ smooth hole to permit passage of the animals from one part to the other. The front of the hutch has two doors, one of wire netting, the other of wood. The wooden door leads to the sleeping chamber and should close tightly. It is best to use metal hinges for the doors. The partition may slide in a groove between the doors or may be put in and taken out through one of the door openings. 
Outdoor hutches should have sloping roofs and overhanging eaves to protect them from rain. The screened door should

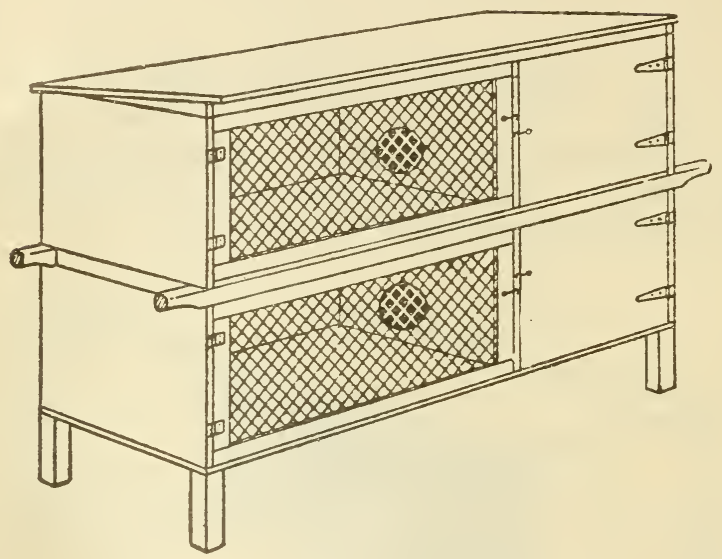

FIG. 2-MOVABLE OUTDOOR HUTCH.

have a sliding cover of wood or be fitted with a removable cloth cover. Small holes bored near the top of the hutch will afford all necessary ventilation.

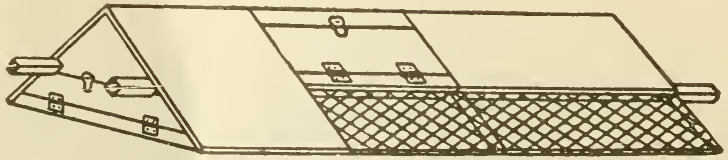

FIG. 3-A SIMPLE MOVABLE OUTDOOR HUTCH.

Movable hutches (Fig. 2) have some advantages. They may be carried outdoors in fine weather and taken back under shelter at night or during storms. Long, narrow cleats pro- 
jecting at both ends of the hutch are all that are needed $t$, convert the ordinary hutch into a movable one. Two forms of outdoor hutch sometimes used are shown in Figs. 3 and 4. That in Fig. 3 has no floor except a wire screen, permitting the rabbits to eat grass or other herbage that projects through the netting.

\section{COURTS}

A rabbit court may be paved or floored, or it may be a grass court surrounded by a rabbit-proof fence. Sleeping hutches inside the court may be small boxes of any sort if they are stout
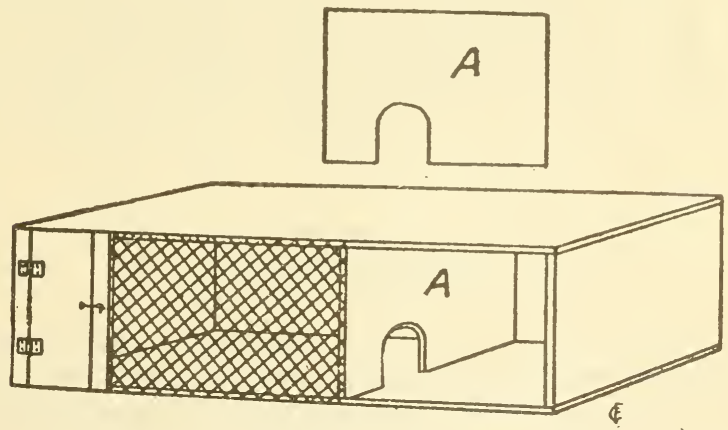

FIG. 4-A SIMPLE OUTDOOR HUTCH.

and waterproof. They should have sliding doors to confine the rabbits if desired, and should also have small holes near the top for ventilation. If a court is used, hutches will still be needed for the breeding does.

A rabbit-proof fence to inclose a grass court should be made of heavy poultry netting 5 or 6 feet wide and of $11 / 2$-inch mesh. The posts, projecting 3 or 4 feet above the ground, should be well set outside the edge of the court. The netting is stapled to the posts, leaving a projection of 6 inches or more at the top 
and about 18 inches at the ground, to be turned into the court. The lower edge should be covered with 10 or 12 inches of soil to prevent the animals from digging out. The upper edge is also turned inward to keep them from climbing over. Brackets at the tops of the posts make the best support for the overhanging netting, although horizontal pieces of wood nailed to the posts will answer.

\section{FOOD AND FEEDING}

The rabbit thrives well on a diversity of vegetable foods. Many writers on the care of this animal prescribe elaborate lists of foods to be followed week in and out. The fact is that a few staple foods are sufficient, but no animal is more adaptable to sudden changes of diet; so that one can feed what is available or cheap, the idea being to produce weight with the least possible outlay of money.

\section{GRAIN AND HAY}

The best grain for rabbits is oats, either whole or crushed, though corn meal, barley, or other grain may often be fed by way of change. The crushed oats are best when freshly broken, and a hand mill for preparing them is a valuable adjunct to a. rabbitry.

Hay is a necessary part of the rabbit's diet and if possible that of the very best quality should be used. It should be entirely free from moldiness, and the unsweated is always preferable. If one has small grounds where suitable grass grows, the mowing may be done at short intervals and the hay thoroughly cured in such small quantities that no sweating takes place. However, if sweet hay is not available the sweated may be fed to the rabbits without injury, unless it be moldy. 


\section{GREEN FOODS}

Rabbits require some green foods for winter. Cabbages, kale, spinach, and rape leaves are recommended. Turnips, beets, and mangels are often fed, and have been recommended by many rabbit breeders, but they do not keep so well as the foods just named. Turnips, unless kept in the ground, wilt by midwinter and are then of little use. Beets and mangels keep better, and the latter are the main dependence of some English rabbitries; but, on the whole, cabbages are more economical, as well as more satisfactory in every way. They are usually available until green stuff grows in the spring. Whatever green food is put away for winter use must be stored where frost can not touch it, as freezing unfits it for rabbit food. Parsnips left in the ground all winter make an excellent early spring rabbit food after the frost leaves the ground in which they grow.

\section{FEEDING}

Rabbits should be fed twice daily. Ordinary stock is fed morning and evening, but suckling does should have also a noon meal or be given more than they will eat at the other meals. The general rule is to feed only as much grain or green stuff as the animals will consume. Hay is put into the hutch to be available at any time, a part of it being left as litter. The exact amount of grain or green stuff for each rabbit at a meal can not be stated, as the appetite varies greatly at different times. Observations of the quantity left over when the animals quit feeding will soon enable the feeder to adjust the meals to the needs of the rabbits. Overfeeding is a much more common mistake than underfeeding.

Winter feeding.--In winter, one of the meals each day should be chiefly of green food (as roots or cabbage), and the other mainly of grain. Roots, cabbage, celery, and the like should be previously washed clean of soil, but should not be wet when 
given to the rabbits. If green food is given in the morning, the evening meal should be whole oats or other grain for mature animals. Those under 3 months of age should be given crushed oats with a little bran, as they can not so well masticate whole grain. A little hay should be given with each meal.

Summer feeding.- - In summer, green food should be the chief reliance, and only a small quantity of hay or grain is needed. Rabbits are fond of all kinds of garden vegetables, besides wild parsley, dandelion, plantain, dock, and other weeds, as well 7i grasses. Agreeable changes in diet are always possible in summer, but overfeeding should be avoided and also the feeding of stuff that is wet with dew or rain. It is best to cut clover or other green food in the afternoon before the dew falls and $t$, spread it under shelter so that it will not heat, but be still fresh at feeding time.

Corrective feeding.-Occasionally a warm mash of cooked potatoes or of the leaves of clover hay mixed with "chops" or a little bran is desirable. Sometimes a little sulphur may b: sprinkled with the mash, although a little flour mixed with the ordinary grain has about as good an effect in correcting looseness of the bowels. In cold weather some breeders feed a warm mash each evening.

Unless green food is abundant rabbits should be given water daily. In warm weather the water pans should be filled with fresh water twice each day. The does suckling young or soon to have young should be given milk diluted with one-third warm water.

A piece of rock salt kept in each hutch affords a steady supply as needed and makes it unnecessary to supply salt in the food.

Rabbits under 3 or 4 months old should be limited in the amount of green food. If allowed too much they are apt to become "pot-bellied." When a young rabbit is seen to grow big about its belly, the use of green food should be discontinued and the animal given plenty of exercise. Under such treatment it 
will soon recover, but if the green food is continued the disease usually terminates in convulsions and death. Old rabbits are not subject to this trouble.

\section{BREEDING}

\section{AGE FOR MATING}

It is not desirable to pair rabbits until they are at least 6 months old, although they may be bred earlier. Some breeders do not mate animals under 10 months of age. Healthy mature rabbits produce larger and stronger litters than younger stock do.

\section{METHODS OF, MATING}

Different breeders adopt different methods of mating. Some leave the buck in the hutch of the doe for but a few minutes, while others leave him over night. The older does should be mated in February, but it is well to defer mating a young doe until March. She then has young in April, when there is abundant green food to induce a good flow of milk. This lacteal development once well established, she is likely always to give abundance of milk for her young. If one begins to pair in February he should expect to have each doe produce four litters a year, the young coming at intervals of about 12 weeks, with a longer rest in midwinter.

\section{PREPARING FOR THE YOUNG}

The gestation period of the rabbit is about 30 days. When the doe is nearly ready to bear young, her hutch should be thoroughly cleaned and disinfected, after which a good supply of soft hay or straw (oat straw is best) should be placed in the body of the hutch to enable the doe to arrange her nest. If the. hutch is without nesting compartment, a box should be placed 
in a corner. It should be 18 to 20 inches long, about a foot deep, 8 or 10 inches wide, and without a lid. Make a hole in one end large enough for the doe to pass through easily, and turn the box upside down. The doe will arrange her nest a day or two before the young are born. At this time extra attention should be given to her food. She should have milk and warm water regularly, and a pan of clean water should be kept constantly in the hutch. While a doe is heavy with young and for a few days after their birth, extreme care should be taken to see that she is not frightened by cats or dogs or even by strange visitors in the rabbitry. Avoid touching the nest or handling the young, unless it is absolutely necessary.

\section{DIET WHILE NURSING}

During the first week or two after having young the doe may be fed almost entirely on warm milk and bread. This is recommended for the bulk of the morning and evening meals, with a small supply of green food. Green food may be given also in the middle of the day, and the daily proportion gradually increased. Boiled mush made of corn meal is also an excellent food for suckling does, but most other pasty or watery foods should be avoided as likely to derange the bowels. Milk, and indeed any soft food, should be fed in a separate earthenware c.isi, especially in warm weather, when it sours quickly. The dish should be often washed and scalded.

\section{NUMBER OF YOUNG}

The number of young produced by the Belgian hare varies greatly. Litters of 10 or 12 occur, but these are too large for a doe to raise. An average of 6 or 7 is all that should be saved. It is of advantage to have several does breed at about the same time, for the number of young may then be adjusted by transferring from those that have too many to those having few. The young begin to leave the nest when about 3 weeks old. At 
this time the nesting box or compartment should be thoroughly clearied and disinfected and then furnished with fresh straw or hay.

\section{WEANING}

The young may be weaned when a month old, but it is better to leave them with the doe two or three weeks longer. Remove two each day until all are transferred to another hutch, which may be large enough to accommodate any number. They do well together until they are 3 or $t$ months old, when their development will compel separation of the sexes. After this any number of does may occupy the same hutch, but bucks, unless thoroughly accustomed to each other, will fight.

\section{MARKETING}

At $t$ months the young Belgian hare should be ready for market, and if it has been properly fed should weigh about 6 pounds or even more. This weight is about the best for market rabbits, and immediate sale is more profitable than keeping to maturity. Some breeders sell at 10 to 12 weeks and aim to have their stock weigh about $51 / 2$ pounds at that age. To do this requires that the animals be kept in small hutches, where they can have but little exercise, and that they be fed heavily from the time they are weaned. Under this treatment they grow very rapidly and are really superior for the table.

\section{MARKET RETURNS}

It is not easy to state what a breeder should realize for market rabbits. Much depends on local conditions, and especially upon the familiarity of the public with the excellence of hutch rabbits for the table. If the animals are new to a market, a demand for them will have to be built up, but as a rule they will soon become popular. Better prices can usually be had by 
selling directly to the consumer, thus saving the middlemen's profit. One may make arrangements to deliver regularly or periodically to hotels and restaurants, but often a poultry dealer will agree to take a certain quantity at regular intervals. A breeder of Belgian hares near a military post in Virginia informs the writer that he finds ready sale for all he can spare at 20 cents a pound, dressed. In England, where rabbits are almost as common in the markets as fowls, the prices paid by poulterers for the carcasses average $5 \mathrm{~d}$. to $6 \mathrm{~d}$. ( 10 to 12 cents) per pound. If as much can be had for them here the rearing of rabbits should be about as profitable as growing poultry for the table. If members of the family look after the rabbits, so that there is no outlay for labor, and if the hutches are built at home, the cost of rearing may be greatly reduced and much of the income will be net gain. While it must be admitted that rabbits require more care than is usually given to poultry on our farms, their management has the advantage that it is more interesting, especially to the younger members of the family.

\section{DISPOSING OF SURPLUS}

After selecting the best stock for breeding purposes it is well to dispose of the remainder as rapidly as conditions warrant. If those to be sold are to be marketed alive, all that is needed is to crate them properly and forward them to their destination. This is the better plan in hot weather, as the carcasses do not keep well. If carcasses are to be delivered the methods of killing and packing are important considerations.

\section{KILLING}

There are two excellent ways of killing the animals. The easier and probably the more humane is to dislocate the neck. Almost all gamekeepers know this method and can quickly show the novice how it is done, but probably a description will be understood. Take the two hind legs of the rabbit firmly in the left hand, place the thumb of the right hand just behind the 
ears where the neck joins the skull, the palm resting on the left side of the face and the fingers holding firmly under the jaws. Then stretch out the animal quickly and with force, pressing in the right thumb and bending the head backward. The dislocation will be distinctly felt. While this method requires considerable strength, when the knack of it is learned it entails less suffering than any other. Another excellent way of killing is to hold the rabbit up in the left hand, as in the first method, and then to strike a sharp blow on the back of the head with a round stick, stunning the animal. As soon as the neck is dislocated or the rabbit stunned the jugular vein should be cut with a sharp knife and the animal hung head downward to bleed.

\section{DRESSING}

The next step in preparing a carcass for market is to remove the paunch and entrails, as their presence would soon taint the meat. With a sharp-pointed knife make a longitudinal cut down the middle of the belly, dividing the skin and the thin abdomen walls, but being careful not to cut the intestines. Turn out the paunch and the intestines, but leave the lungs, liver, heart and kidneys in place. Next make a slit between the large tendon and the bone of one hind leg and slip the other leg through the cut, so that the carcass may be readily hung up. It should hang long enough to stiffen before being packed.

\section{PACKING}

For packing the rabbits for market a basket or hamper of the ordinary shape and having movable flat slatted trays to enable one to pack the carcasses in separate layers is recommended. Such a hamper permits free circulation of the air not only on the edge but also throughout the package, and the carcasses packed this way reach their destination in an attractive state instead of the messy condition so often seen in the wild rabbits marketed in America. 


\section{RABBIT SKINS}

An enormous trade in rabbit skins is carried on abroad. Throughout Europe practically all the skins of marketed rabbits are saved. 'The number produced in Great Britain and Ireland is estimated at about 30,000,000 annually; while, according to the English trade returns for 1910, there were imported during that year undressed rabbit skins to the number of $82,327,101$. Of these over 11 millions came from Belgium, nearly + millions from France, upward of 43 millions from Australia, and 7,379,960 from New Zealand. Most of the skins are sold in bales by weight and only the fur from them is utilized in making felts and other cloths. The better skins, however, command good prices and are made up into garments in imitation of more costly furs. Skins of arctic hares and white rabbits are used to imitate ermine and arctic fox. Skins of Angora and silver gray rabbits sometimes sell for a shilling or more each. Belgian hare skins are usually dyed to imitate black fox or the so-called "black lynx." They are worth several cents each when untorn.

\section{AILMENTS OF RABBITS}

If properly cared for, rabbits are remarkably free from diseases. The more common ailments result from insanitary surroundings, lack of care in feeding, and improper ventilation. The hutches should be frequently cleaned and fresh sawdust or other fine litter used to take up liquids, so that the hutches do not become foul. Such ailments as mange, scurf, surfeit, and the disease of the eyes known as ophthalmia are due usually to foul hutches. Cold snuffles and the like result from improper ventilation, sudden draft of cold air in overheated buildings, and similar causes. The disorders of the digestive organs come from feeding young rabbits too freely of wet and juicy green foods or from too radically changing their diet. Most diseases are 
preventable, and if the cause is understood, remedies will suggest themselves. For pot belly, constipation, and like ailments, exercise is the best remedy. If constipation continues, a diet of soft foods or a little castor oil usually gives relief. For diarrhea a little dry barley meal is good, and sometimes powdered acorns in skim milk are an effective remedy.

Incrustations known as ear canker, and accumulations of ear wax may be cured by mechanically removing the incrustations with the aid of lukewarm water, and then washing with a soft sponge and applying powdered boracic acid. 'The animal should be held by an assistant. The treatment often requires repeated daily application.

The most serious disease known among hutch rabbits in America is coccidiosis. It is caused by internal parasites, and when present in the rabbitry kills many young rabbits. Extreme caution is needed to prevent its introduction, and new stock obtained should for a time be kept isolated from the regular hutches. Keeping the hutches in stacks helps to spread the infection. Absolute cleanliness may do much to prevent the disease. Whenever a number of the young rabbits under good care assume a pot-bellied appearance, particularly where it is accompanied by symptoms of cold and snuffles, there is reason to suspect that old and apparently healthy animals may be afflicted with chronic coccidiosis and are expelling coccidia from their bodies. Isolation of the affected hutch and its occupants, together with disinfection, are the first steps to be taken while the exact nature of the irouble is being determined.

If serious diseases affect his stock, the amateur will find it advantageous to obtain a standard treatise on the management of rabbits. This will contain detailed instruction for the treatment of the more common ailments. As the business of rearing rabbits is carried on much more extensively in England than in America, the best hand-books are published abroad. They may be obtained through any bookseller. 


\section{CONCLUSION}

While not affording large profits, the business of raising rabbits in a small way may be made an interesting as well as a reasonably remunerative adjunct to other pursuits. It is adapted to small village places, as well as to farms, and under careful management the returns from it are likely to increase as one gains experience. Under favorable circumstances it is capable of expansion into a serious vocation. The presence of rabbits in inclosures on the farm or on village premises furnishes opportunity for an agreeable change in the family diet, a fact that is of considerable importance when ordinary meats are high priced, or in regions where they are difficult to obtain. 


\title{
New Zealand Red Rabbits
}

\author{
BY C. P. GILMORE.
}

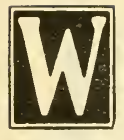

ITH the steady and almost prohibitive increase in the cost of meat one of two means of escaping is offered us; either to forego meat altogether or use it rarely as a luxury, or develop some other source of supply. Man belongs to the meat eating family; this is indicated by his teeth and his digestive organs. Meat is is a condensed form of food and a smaller amount of it will supply the needs of the body than will the average forms of vegetables. Therefore the probability is that to satisfy his craving for meat food, he will take the alternative and turn to some other source of meat supply than that offered in cattle and hogs, and this source will be found in chickens and rabbits, and especially rabbits.

Indications are very strong in this direction already. Never since the insane Belgian hare craze which swept over this country some twenty years ago has there been so great an interest manifested in rabbits as at the present time. Hundreds have taken up the culture of rabbits as a sole occupation and are making good. There are three important branches at present, and in the near future there will be four. They are: Market breeding, private dressed rabbit trade, home consumption, and the fourth will be the fur.

The Belgian hare and the Flemish Giant have been the leading varieties from a commercial standpoint; but there is another rabbit that is at present commanding the attention of the rabbit breeders of this country, and that is the New Zealand Red. This breed, it is believed, was imported into this state (California) in 1906, but they have been so greatly improved by the California fanciers during the past four years that one wonders if it were possible. 
At the present time they are the leading variety on the Pacific Coast, this fact being due to their splendid qualities more than any special advertising, for it was only last year that we organized the National New Zealand Red Club, which is giving the breed widespread publicity. At the Los Angeles show, January, 1915, there were over 100 on exhibition, almost doubling the next class beneath them. Los Angeles, as you must know, is one of

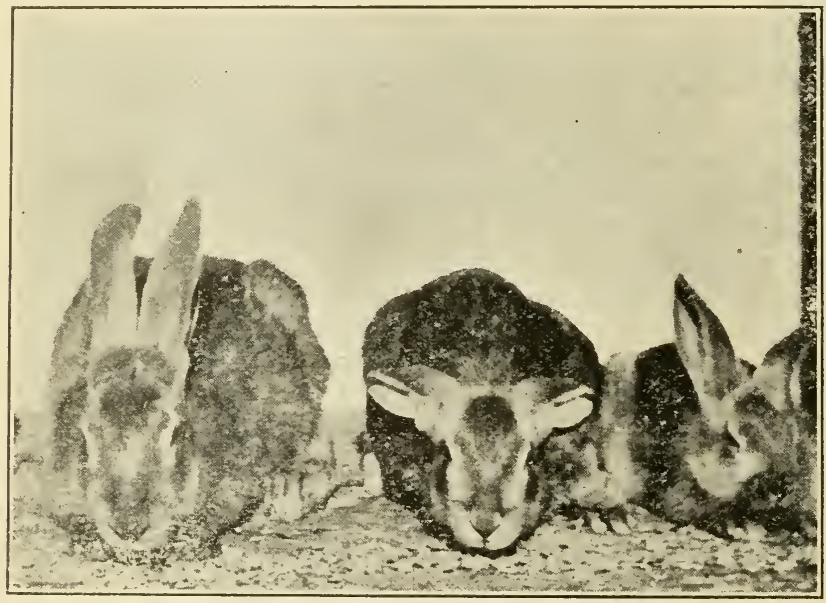

New Zealand Red Rabbits, 1, 2 and 3 months of age. Gilmore's Rabhit Farm. the largest rabbit markets in America, and in this county you will probably find more successful market breeders than in any other one county in the country, these breeders nearly all breeding the New Zealand Red. Why? Here are some of the rexsons: First, they breed true to color. Second, they mature rapidly, making fine fryers at from seven to ten weeks. Third, tha does are splendid mothers. Fourth, they are medium boned and at eight or nine weeks you have a plump fry instead of a large bone and lean fry, Fifth, with few exceptions the bucks car 
be raised together until they are seven months old and will not fight; this means a big item in the saving of hutch space as well as extra work. Sixth, as exhibition rabbits they are unequaled. There is a fascination about their rich, reddish buff color that appeals to the eye of the true fancier, and the longer one breeds them the more fascinating they become. In the show room the

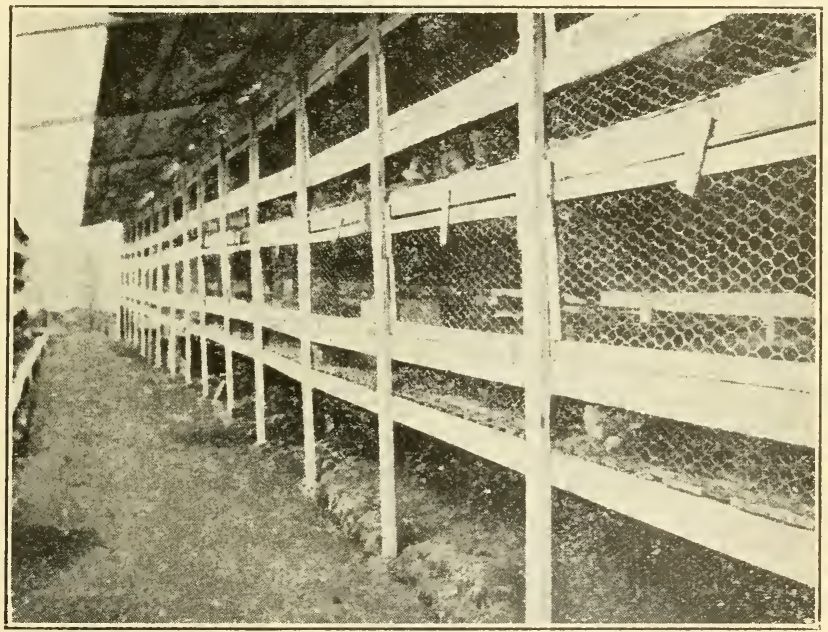

A Row of Hutches. Gilmoxe's Rabbit Farm.

attract a great deal of attention from the uninterested public which in many cases results in making fanciers.

For the past two years the demand for first-class New Zealand breeding stock has been splendid, and as time goes on this demand keeps growing. Every breeder of New Zealands will tell you that business is good.

Santa Barbara, Calif. 


\title{
The Black Siberian Hare
}

\author{
R. H. COWAN.
}

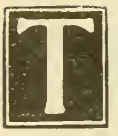

HE Black Siberian hare is the latest addition to the various varieties of rabbits or hares.

All admirers of this newly found breed claim that it is going to take the place of the wild fur-bearing animals, which are fast becoming extinct, and that its fur will fill a gap between the very expensive Black Fox skin and the cheaper furs, such as those of the common rabbit, the muskrat, etc.

The fur of the Black Siberian hare can be produced at a very low cost, and careful breeding will bring it to a high state of perfection. Sufficient proof for this statement is found in the colors and shapes to which pigeons, fowl and other animals have been bred.

The advantage of breeding to perfection in this animal is greater than in almost any other, as two generations can be produced in a single year, because they breed very young. Thus, by breeding only from animals selected for the quality of their fur, perfection can soon be reached.

The Black Siberian Hare is indigenous to Siberia. The animal therefore requires a thick, tough pelt, and close warm fur to protect it from the cold of its native country. In fact, its skin is as thick as that of muskrat, mink or marten, and its fur is a rich glossy black. Sometimes, however, a silver gray will appear.

As the Black Siberian comes from a country that has a decided summer and winter, he does not continue changing his coat all through the summer, and partly so through the winter, as do rabbits and hares bred for numerous generations in mild 
climates. In the latter case the skin of the rabbit or hare is almost useless.

The Black Siberian Hare, like other good fur-bearing animals, has a light summer coat. This he changes in the fall for a thick, black winter coat (sometimes silver gray). The skin then is in season and is very valuable, whether black or silver gray.

This Black Siberian Hare is of enormous size, maturing so rapidly that at six months a good specimen will weigh ten pounds. The flesh is delicious, being between the flavor of chicken and that of spring lamb. This animal is also very hardy. It can stand the severest winter without any protection from cold. It will breed as freely as common rabbits and its young grow much faster, being at three months old the size of a full grown Belgian hare. They are more sprightly and active than a common rabbit, can jump five feet high and therefore require a high fence to enclose them.

In appearance these hares are long, round in the body, and quite tall. They stand more upright than the common rabbit, being more deer-like, especially when running.

In color they resemble the Black Fox; the great majority are black, but occasionally a handsome silver gray appears, as is also the case among Black Foxes.

At present the Black Siberian Hare is very rare in America. Only a few pairs have as yet been imported to North America. They are not even numerous in Siberia, being found wild only in a few places and those in dense swamps where the animal has no protection from beasts of prey. This last fact prevents them from becoming numerous. Thus it is evident that they have not been allowed to increase fast, even though their reproductive power is so great when they are protected from their enemies.

One of the Black Fox fur companies has imported a few of these Black Siberian Hares with the idea of breeding them in conjunction with Black Foxes. They hope to utilize the flesh 
of the hare to feed the foxes, and at the same time receive a handsome profit from the skins. Let us now compare the Black Siberian Hare with the Black Fox.

The Black Siberian Hare is as large if not larger than the Black Fox. The Black Fox is a carnivorous animal and each one eats about twenty-five dollars $(\$ 25.00)$ worth of meat in a year. The Black Siberian Hare, being a herbiverous animal, can be fed for a year at a cost of eighty cents $(80 \mathrm{c})$.

The Black Fox is a monogamist and a male must be kept for every female. Even then they sometimes fail to mate. The Black Siberian Hare, however, is a polygamist and one male will do twenty or more females.

The Black Fox breeds but once a year, and even this once is very uncertain. The Black Siberian Hare, with good management will breed almost every month in the year and in each batch there are more young than in the one batch of the Black Fox.

Therefore it can readily be seen that although the fur of this hare is not so valuable as that of the Black Fox, still, breeding the Black Siberian Hare for its fur gives the owner far more satisfaction and has many advantages over breeding Black Foxes.

Besides, all thinking people now realize that the vast prairies of the Northwest, that pastured thousands of cattle and sheep free of cost to their owners, have been claimed by human settlers and used for other purposes. This has raised the price of beef and mutton until now they are almost beyond the reach of even the well-to-do people, and they are still soaring in price. But this problem must be solved, because people accustomed to eating meat cannot exist without it. Here, then, is a substitut? for both cheap meat and cheap fur, namely, the Black Siberian Hare.

Hamilton, Ont., Canada. 


\section{A Hobby For the Ladies}

Mrs. B. F. Wilcoxon.

HE prevalent discontent of women on the farm, and the wholesale rush of our young people to the cities, is one of the greatest social problems of the age. It is necessary for a woman to have a hobby, or an interest in life. The great trouble with women in rural districts is that they are mentally asleep, and nothing short of a hobby will bring out the best there is in them.

I often wonder why more boys, girls and women do not take up the breeding of Belgian hares. I know very few boys and girls who keep and breed rabbits. I cannot do better than hammer at this subject as a means of earning money at home. Why not interest the ladies in the rabbit-breeding business? It is no use advising the ladies to go in for breeding rabbits unless there is a good chance of their being able to earn something in return. A short time ago, while visiting rabbit breeders in Denver, I came across a rabbitry of some five hundred numbers; the business was carried on by a woman as a means of earning a living.

"Oaks from little acorns grow."

Fanciers achieve great things from modest beginnings. IVe are often told by the narrow-minded individuals that one has to be "in the swim" to succeed. But hundreds of beginners have come to the front at a rapid rate. The Belgian hare offers "as rosy prospects as does any other variety." It has been referred to as the "Business" rabbit of the fancy. Many fanciers have found the breeding of Belgian hares a paying hobby. Many are making quite a sum of money every year from their rabbits; some even paying their house rent and adding to their income from the profits on rabbits. Last winter when I could not raise chickens I raised rabbits. Eat some Belgian hare meat and you will try to raise enough for your own table at least. They make fine pets for children. Every boy loves rabbits. Lots and lots of boys never know the pleasure of having some rabbits of their 
own to care for. If you want to start your boy into a business get him a pair of rabbits and watch him enjoy them. They increase like compound interest. Does can be bred six or eight times a year. The hare can be raised to five months of age for three cents per pound.

The meat at the shops sells for 20 to 25 cents per pound. In Denver, Colo,, there is as much rabbit meat used as chickens. The body is nearly all meat, which is greatly in their favor. Not half of the meat side of the Belgian industry has been told, nor can it be at present.

A hobby that will pay its way is one to be valued.

Hobbies often become a business even though they may not become the one business in life. A man who manufactures every-day articles long since took up the breeding of Jersey cows purely as a hobby. What was the result? He began exhibiting, and to-day there is as great a demand for his Jersey cows as there is for the product of his business. The man's motto in business is: "One quality - the best," and his make is superior that to think of the article is to think of his name. 'That principle he has carried into his hobby, and made it as great a success as his business.

The rabbit shows held in. Leipzig are the largest in the world. The last show there was an entrance of over $2,800 \mathrm{rab}-$ bits. The rabbit breeding industry in Germany has developed enormously the last fifteen years. The demand has also developed so rapidly that rabbit meat has to be imported from other countries.

France breeds and consumes more rabbits than any other country in the world. One year over eighty million rabbits were sold in the markets of France. Many for years find their hobby and relaxation from the cares of business in the breeding of rabbits for exhibition. May not others be able to find their hobby in breeding rabbits for the market?

We have to-day many large poultry farms scattered up and down the country, some are run entirely for the production of high-class exhibition stock; we also have farms that never touch 
the exhibition side, but stick closely to utility matters. Is it not possible to have the same state of things prevailing in regard to rabbit keeping? England prides herself on her great rabbit shows.

The chief points in starting in Belgians are: First, hutches that are free from dampness; second, food the very best grain, all kinds of green food, and all kinds of roots; third, the stock; well, the best are the best, so get one or two as good as you possibly can in preference to several inferior ones. The best start is a doe in kindle or a pair. Don't start with too many at first; learn and then increase your number. There is an art in every trade, including breeding rabbits. According to some, money rolls in the fancy; but, well, some people's geese are "swans."

The other day I received a letter from a lady who got the Belgian hare fever who took the wrong turn; but, of course, experience has taught her much. I know she does not mind my telling, because it should act as a help to those about to start. She writes:

"When I come to look on the past and study where my failings have been, I have not far to look. I started in what I now see was a foolish fashion. I got one from here and one from there; this out of a selling class and that out of a prize winning class-all good rabbits as far as markings were concerned, but of their pedigree 'I did not know anything. What a 'mess of pottage' to be seen and the dish was my downfall. You have to live and learn, and, to my cost, in both time, labor and money I found out it was no use of trying to breed from such an assortment. I got to the end of the lane at last and then went to a reliable breeder. I laid down my case, acknowledged my sin, as it were, and since that time I have no reason to regret the latter policy."

My friend's acknowledgment is quite sensible; there is no doubt that obtaining stock from all different parts of the compass is a wrong policy to pursue. The old proverb, "As ye sow so shall ye reap," comes forcibly into the limelight.

I believe in the theory: that there is more room at the top 
of the ladder than at the bottom. Certainly there are a greater number struggling at the bottom; yes, a great number who never get one bit higher. If you have the true fancier's spirit you will not begrudge the time of waiting, whilst you will be all the better for it. "Patience is a virtue," we are told, and it is doubly so with the fancier who is blessed with a good dose of it. Oh, never mind, "Little drops of water, little grains of sand." No one can afford to neglect any trifle, however minute or apparently insignificant, that goes for improvement; attend to these apparently trifles and success will follow. The fancier who says, "Oh, never mind, that's too much trouble," will never succeed.

Nothing thrives unless it is comfortable, can be taken as a safe maxim. Even a pig, the dirtiest of all animals, likes a comfortable bed; yes, and thrives on it. To provide stock with a comfortable bed is true economy.

\section{VALUED MORE THAN MONEY.}

I quote the following for the reason that it illustrates the fascination that the fancy has for its owners. A gentleman went to a large fancy show to purchase a buck to mate with a well bred doe he possessed. He bought a winning buck, paying a good price for him. A few nights afterwards the door of his hutch was accidentally left open, a dog got in and killed the v. 1 bred buck referred to. Of a speculative turn of mind the owner has won and lost vast sums of money, but his closest friends say that they never saw any thing worry him like the loss of this particular rabbit. "I have seen him lose a thousand dollars in one afternoon, and it made no perceptible difference in his demeanor," said the friend, "but you should have seen him when the dog nabbed that rabbit. I never saw hirin so mad."

North Platte, Neb. 


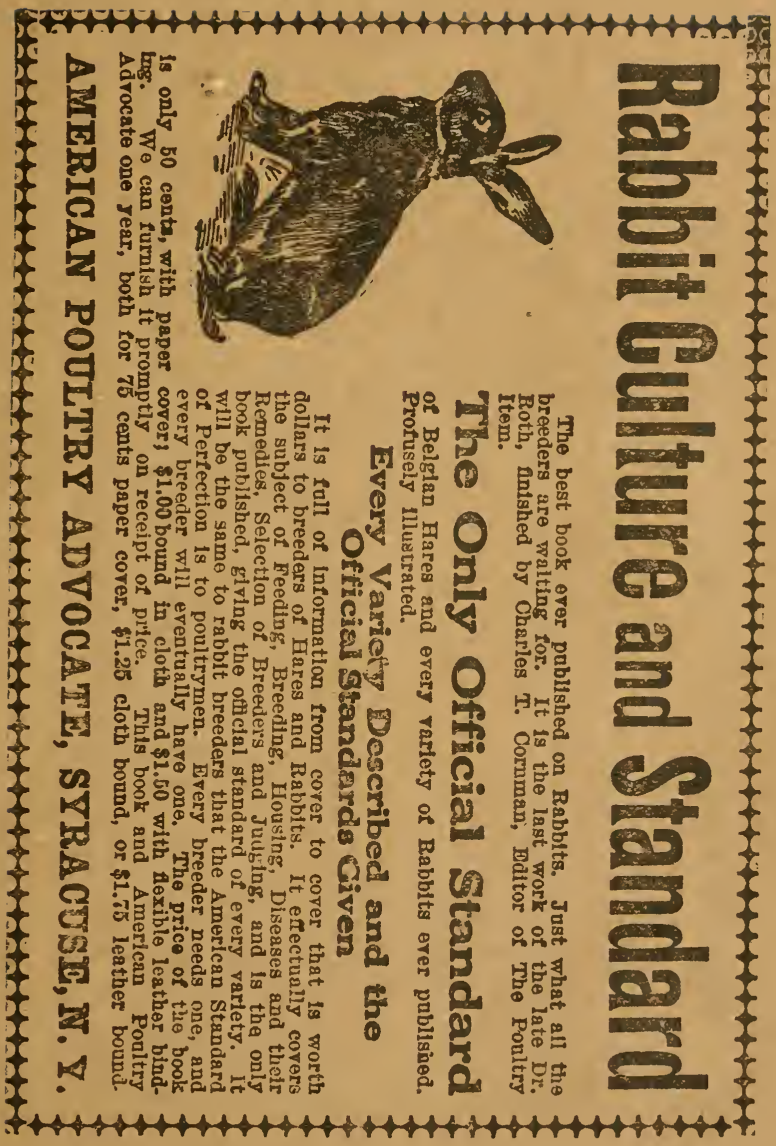




\section{LIBRARY OF CONGRESS}

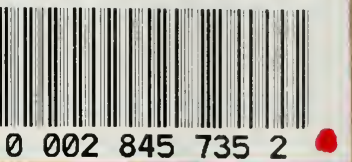

\section{"The Whole Thing in a Nutshell."}
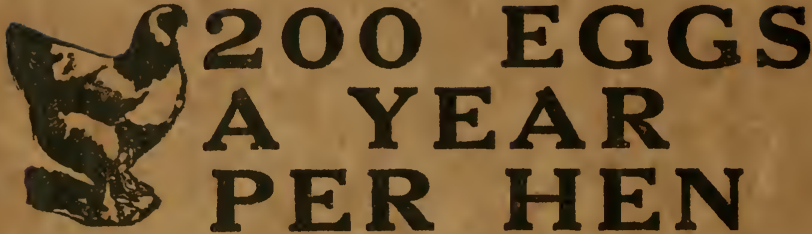

\section{HOW TO GET THEM}

The elghth edition of the book, "200 Eggs a Year Per Hen," is now ready. Revised, enlarged, and in part rewritten. 96 pages. Contains among other things the method of feeding by which $\mathrm{Mr}$. S. D. Fox, of Wolfboro, N. H., won the prize of $\$ 100$ in gold offered by the manufacturers of a well-known condition powder for the best egg record during the winter months. Simple as $a, b$, c-and yet we guarantee it to start hens to laying earlier and induce them to lay more eggs than any other method under the sun. The book also contains recipe for egg food and tonic used by Mr. Fox, which brought him in one winter day 68 eggs from 72 hens; and for five days in succession from the same flock 64 eggs a day. Mr. E. F. Chamberlain, of Wolfboro, N. H., says: "By following the methods outlined in your book I' obtained 1,496 eggs from $91 \mathrm{R}$. I. Reds in the month of January, 1902." From 14 pullets picked at random out of a farmer's flock the author got 2,999 eggs in one year-an average of over 214 eggs aplece. It has been my ambition in writing "200 Eggs a Year Per Hen" to make it the standard book on egg production and profits in poultry. Tells all there is to know and tells it in a plain, commonsense way.

Price 50 cts. or with a year's subscription, 75 cts.; or given as a premlum for two yearly subscriptions to the Amerlcan Poultry Advocate at 50 cents each.

Our paper is handsomely illustrated, 44 to 116 pages, 50 cents per year. 3 months' trial 10 cents. Sample free. Catalogue of poultry books free.
AMERICAN POULTRY 1009 SOUTH SALINA STREET,
ADVOCATE, SYRACUSE, N. Y. 


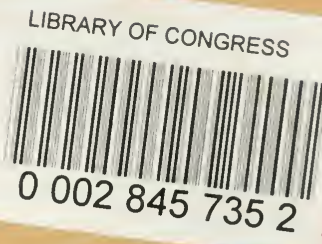

